\title{
Article
}

\section{Riparian Vegetation Density Mapping of an Extremely Densely Vegetated Confined Floodplain}

\author{
István Fehérváry ${ }^{1,2} \mathbb{D}$ and Tímea Kiss ${ }^{2, *(\mathbb{D})}$ \\ 1 Directorate for Environmental Protection and Water Management of Lower Tisza District (ATIVIZIG), \\ Stefánia 4, 6722 Szeged, Hungary; FehervaryI@ativizig.hu \\ 2 Department of Geoinformatics, Physical and Environmental Geography, University of Szeged, \\ Egyetem u. 2-6, 6722 Szeged, Hungary \\ * Correspondence: kisstimi@geo.u-szeged.hu or kisstimi@gmail.com; Tel.: +36-62-544-545
}

Citation: Fehérváry, I.; Kiss, T. Riparian Vegetation Density Mapping of an Extremely Densely Vegetated Confined Floodplain. Hydrology 2021, 8, 176. https://doi.org/10.3390/ hydrology 8040176

Academic Editor: Pingping Luo

Received: 12 November 2021 Accepted: 27 November 2021 Published: 30 November 2021

Publisher's Note: MDPI stays neutral with regard to jurisdictional claims in published maps and institutional affiliations.

Copyright: (c) 2021 by the authors. Licensee MDPI, Basel, Switzerland. This article is an open access article distributed under the terms and conditions of the Creative Commons Attribution (CC BY) license (https:// creativecommons.org/licenses/by/ $4.0 /)$.

\begin{abstract}
The most crucial function of lowland-confined floodplains with low slopes is to support flood conveyance and fasten floods; however, obstacles can hinder it. The management of riparian vegetation is often neglected, though woody species increase the vegetation roughness of floodplains and increase flood levels. The aims are (1) to determine the branch density of various riparian vegetation types in the flood conveyance zone up to the level of artificial levees (up to $5 \mathrm{~m}$ ), and (2) to assess the spatial distribution of densely vegetated patches. Applying a decision tree and machine learning, six vegetation types were identified with an accuracy of $83 \%$. The vegetation density was determined within each type by applying the normalized relative point density (NRD) method. Besides, vegetation density was calculated in each submerged vegetation zone (1-2 m, $2-3 \mathrm{~m}$, etc.). Thus, the obstacles for floods with various frequencies were mapped. In the study area, young poplar plantations offer the most favorable flood conveyance conditions, whereas invasive Amorpha thickets and the dense stands of native willow forests provide the worst conditions for flood conveyance. Dense and very dense vegetation patches are common in all submerged vegetation zones; thus, vegetation could heavily influence floods.
\end{abstract}

Keywords: riparian vegetation; LiDAR; machine learning; NRD; flood level increase

\section{Introduction}

In Europe, floodplains cover ca. $7 \%$ of the continent's area, and they exhibit unique morphological, hydrological, ecological and pedological characteristics [1]. Very often, they are artificially confined; thus, the flood conveyance is restricted to a narrow zone. The essential function of this zone is to support safe flood conveyance without any negative impact on flood-protected areas. In lowland floodplain areas where the rivers have low slopes and low velocities, the main aim of flood management is to fasten the flow and decrease the flood duration. For example, in Hungary, the Tisza River has very low slope $(1-1.5 \mathrm{~cm} / \mathrm{km})$. Thus, floods last for months; therefore, the main aim of flood mitigation is to shorten the floods instead of their retention, thus increasing the flood conveyance of the artificial floodplain. In case of declining flood conveyance capacity of confined floodplains, the probability of an artificial levee overtopping or breaching increases, endangering citizens, settlements or infrastructure built on the flood-protected side of the floodplain [2].

The flood conveyance is the discharge conveyed through a given channel-floodplain reach at a given overbank stage [3]. It is dependent on channel geometry and any factor affecting flow velocity (e.g., slope, roughness, hydrology). The floodplain vegetation is an important factor in flood conveyance, as it fundamentally influences the roughness of the floodplain [4-6], thus the flow velocity and the level of overbank floods [4,7-9]. In addition, the densely vegetated plots can divert the overbank flow, creating high-velocity flow paths on sparsely vegetated areas [7] and almost-standing water at dense vegetation patches [10]. 
The efficiency of flood flow modification of the floodplain depends on the vegetation type [4] and whether they are emerged by low stages or submerged by high flows having various degrees of resistance [11]. Herbs, grasses and some shrubs have flexible stems, while larger shrubs and trees have rigid trunks, influencing flow resistance and flood capacity at various degrees [12]. The emergent vegetation with rigid stems effectively decreases the overbank flow velocity, dissipates wave energy and changes the turbulence conditions [13-15]. The effectiveness of the vegetation depends on the rigidity of the stems [13], their density [15] and spatial distribution [12,14], the height of the water column above the vegetation [13-15], and the existence of foliage [12,14]. The dead further increases the roughness of the floodplain, influencing the hydrology of floods [16].

The flow modification caused by floodplain vegetation results in altered hydrologic and geomorphic processes on the floodplain [15,17-19]. Plants have a channelization effect: they can impede overbank flow on the floodplain, decreasing its velocity in some cases even to $0 \mathrm{~m} / \mathrm{s}$ [9], while the flow velocity in the channel increases [9]. Thus, the velocity differences between the channel, the bank, and overbank areas increase, influencing their geomorphological processes $[7,9,20]$. The increasing vegetation density promotes the velocity drop of the overbank flood flow; thus, it increases floodplain aggradation [16,21]; however, after a threshold roughness value, the process turns over, and the too dense vegetation impedes water movement; thus, the rate of sedimentation decreases [10]. The locations with increased sedimentation can be the hotspots of the deposited solid pollutants, like micro- and macroplastics.

Currently, the native riparian vegetation faces new challenges, as it should quickly be adapted to climate change, increasing human impact, and the spread of invasive plant species $[22,23]$. The green eco-corridors along rivers provide perfect routes for spreading alien plants, significantly if the hydrological conditions change. In Central Europe, in Hungary, the floodplains are considerably invaded by invasive plants. The false indigo (Amorpha fruticosa) and the box elder (Acer negundo) have woody stems and grow in great density as an understory of every plant association. Thus, they can influence the floodplain roughness and flood conveyance capacity effectively [23], while the climbing American Vitis species and wild cucumber (Enchynocystis lobata) can create an impenetrable cover on trees and bushes [24]. Besides their negative role on flood conveyance, these species (especially the Amorpha) influence the nutrient condition of riparian soils, decrease the riparian plant diversity by altering ecosystem functions, and produce a conspicuous shift in species composition [25]. Therefore, it is necessary to control invasive species on the floodplain both from ecological and hydrological perspectives. Ecologists suggest cattle grazing as an effective practice [26], providing more favorable habitats for native species and thus restoring the original flow conditions of the floodplain.

The various morphometric parameters of the vegetation (e.g., number of individuals, canopy density and height) could be studied by field measurements and remote sensing methods. Applying field measurements, these parameters could be evaluated with high accuracy under controlled conditions [27,28]; however, these measurements are very timeand labor-intensive, and can be applied only on a limited number and size of study sites. On the contrary, remote sensing methods have the advantage that they can be applied over large areas. However, instead of measuring the parameter of the vegetation directly, it can be determined indirectly from the reflection or absorption of the emitted electromagnetic energy [28].

In recent decades, LiDAR technology has played a key role in the 3D study of vegetation structures [29]. Some of the radiation emitted by LiDAR is reflected by the canopy and the understory plants, providing comprehensive data on vegetation structure [29]. Over the last 20 years, with the development of data processing techniques, many studies have been published on the analysis of understory structure. For example, Chasmer et al. [30] compared parameters calculated from the field and airborne LiDAR data with field-measured reference values in a closed red pine forest. Morsdorf et al. [31] used airborne LiDAR data to investigate vegetation levels in Mediterranean forest ecosystems. Hahmraz et al. [32] 
found that based on point clouds with (density $\geq 170$ points $/ \mathrm{m}^{2}$ ), trees below the primary canopy layer can be well delineated, and the understory can be investigated in detail. Scanning the lower forest canopy has been used to map firefighting routes [33] or investigate the spread of the invasive Ligustrum sinense in urban green areas [34].

Various LiDAR-based methods can be used to describe the density of vegetation levels within forests. They are based on the fact that the denser the vegetation in a given zone, the more likely the reflection is from the zone. However, it is important to note that in the case of very dense vegetation high-resolution point cloud is required due to the absorption of pulses [33]. Riano et al. [35] used cluster analysis to separate points reflected by the canopy from points in the understory and then used the overall relative point density (ORD) method to analyze understory density. The ORD is calculated by dividing the number of points in a given volume of vegetation by the total number of points in the same area $[34,36]$.

$$
\operatorname{ORD}(i, j)=\frac{\sum_{i}^{j} n}{\sum_{0}^{k} n}
$$

Thus, the number of points $(n)$ that fall between $i$ and $j$ height zone is divided by the total number of points in a given area from the ground level (height $=0$ ) to the height of the highest point $(k)$. Jakubowski et al. [37] modified the ORD calculation to use understory vegetation density as a parameter to estimate wildfire spread. Martinuzzi et al. [38] used a random forest algorithm to select those parameters that best describe understory vegetation density. Their results also reflect that the ORD value of surface points and the ORD value of the vegetation zone between 1-2.5 m are related to understory density.

Another method often used to characterize forest canopy is to calculate the normalized relative point density (NRD) parameter $[27,33,39,40]$. NRD is calculated by dividing the number of points in the elevation zone of interest by the sum of the points in the zone of interest and the points below it.

$$
\operatorname{NRD}(i, j)=\frac{\sum_{i}^{j} n}{\sum_{0}^{j} n}
$$

The NRD parameter was introduced by Seielstad and Queen [29] to determine the vegetation density in the 0-3 m height zone. Goodwin et al. [39] calculated NRD values for vegetation levels between 0.5 and $4 \mathrm{~m}$ and compared these with field density estimates, finding a strong correlation between the parameters. Skowronski et al. [41] used NRD values to analyze the vegetation's vertical structure, concluding that NRD values for 1-2 $\mathrm{m}$ and 2-3 m levels are closely related to the presence of understory. Campbell et al. [28] used the conventional photo-based density measurement technique as reference data to compare the effectiveness of ORD and NRD methods. Their results indicated that the NRD computation method more accurately represents the density relationships of the understory vegetation in the sample area than using the ORD technique, as the NRD method filters the effects of the overstory at a higher rate.

Previous LiDAR-based studies have assessed vegetation density inhomogeneous forests, although natural forests can be composed of various associations. For example, natural poplar and willow forests, thickets, grasslands, planted forests, and mixed vegetation patches are typical on floodplains. Besides, the understory layer of the same vegetation type can vary significantly due to the spread of invasive species, which might form impenetrable shrubbery. In the artificially confined floodplains of Central Europe, riparian vegetation is becoming progressively dense, increasing the roughness of the floodplain and influencing flood flow conditions [42]. For example, along the Tisza River (Hungary), by the end of the 20th century, a rapid spread of invasive species (e.g., Amorpha fruticosa, Acer negundo, Vitis riparia, Enchynocystis lobata) was observed as the result of the abandonment of agricultural fields, mismanagement of forests, climate change and the subsequent hydrological changes. Besides, in the 1990s and 2000s, extremely high and long-lasting floods were on the Tisza River, which the native understory plants did not tolerate. Ever since, the 
flood-free years created favorable conditions for invasive species, which have become dominant in the shrub layer of all riparian forests, forming dense understory vegetation with high vegetation roughness [9]. However, to model the impact of changing vegetation on flood waves, accurate data on vegetation density is required over the entire confined floodplain (several $100 \mathrm{~km}^{2}$ ). Nevertheless, this data cannot be produced by traditional field-based techniques. Furthermore, the vegetation is so impenetrable that it is impossible to walk through and make measurements in it.

Therefore, the paper's main focus is to define vegetation density on a low-slope floodplain. The objectives of the research are (1) to identify the riparian vegetation types using automatic classification; (2) to determine the vertical branch density of vegetation in the active floodplain in the flood conveyance zone (i.e., $1-5 \mathrm{~m}$, thus up to the level of the artificial levees); and (3) to assess the horizontal and vertical spatial distribution of densely vegetated patches, which might influence the propagation of the flood wave. The created accurate vegetation density data could be used in future hydrological modelling, and the role of invasive species could be determined on flood conveyance. The results could support the management of the riparian vegetation from the point of view of flood mitigation. The analysis of the density of various vegetation types helps to highlight those vegetation types that should get more attention during management, and the knowledge on the spatial distribution of dense vegetation patches could help to plan the weeding to support flood conveyance. Finally, the applicability of the LiDAR-based NRD parameter was also evaluated in the studied extreme dense inhomogeneous riparian vegetation.

\section{Study Area}

The study was carried out on the lower reach of the Tisza River in Hungary, Central Europe (river length: $962 \mathrm{~km}$; catchment area: $157,200 \mathrm{~km}^{2}$; [43]), $8 \mathrm{~km}$ north of the city Szeged. The selected floodplain area is $2 \mathrm{~km}$ long, and its area is $3 \mathrm{~km}^{2}$ (Figure 1). Floods in the Tisza River typically occur in early spring caused by snowmelt and in early summer due to rainfall [43]. Floods on the Lower Tisza can last for 1-3 months [44] because the low slope $(1-1.5 \mathrm{~cm} / \mathrm{km})$ is combined by impoundment during simultaneous floods of the tributaries and the Danube River. On the Lower Tisza, at Szeged, the maximum discharge (1932: $4346 \mathrm{~m}^{3} / \mathrm{s}$ ) is 27 times greater than the minimum value (1946: $\left.160 \mathrm{~m}^{3} / \mathrm{s}\right)$. The height difference between the lowest and highest stages is $13.1 \mathrm{~m}$ in the study area at Algyő. The flood height has increased continuously since river regulations in the mid-19th century; thus, new flood records were registered 11 times at the Lower Tisza [10,44]. The horizontal spread of floods is controlled by artificial levees (embankments). The last record flood in 2006 already reached the top of the levees; thus, a 5-6 m high water column was formed in the confined floodplain.

The channel flow velocity is up to $1.2 \mathrm{~m} / \mathrm{s}$ [44]; however, the mean water velocity in the floodplain is below $0.1 \mathrm{~m} / \mathrm{s}$, while in areas with dense vegetation, the water velocity drops to practically $0 \mathrm{~m} / \mathrm{s}$ [10].

Anthropogenic interventions have significantly modified the meandering channel and wide natural floodplain of the Tisza River since the mid-19th century [43]. Altogether 112 meanders of the river have been artificially cut off, reducing the total length of the Tisza River from $1414 \mathrm{~km}$ to $962 \mathrm{~km}$. Alongside the Tisza River and its tributaries, a $4500 \mathrm{~km}$-long artificial levee system was built; thus, the several 10-km-wide natural floodplains was confined to a $1-5 \mathrm{~km}$ wide zone. In the 20th century, bank protections and spurs were constructed to prevent bank erosion and protect artificial levees. 


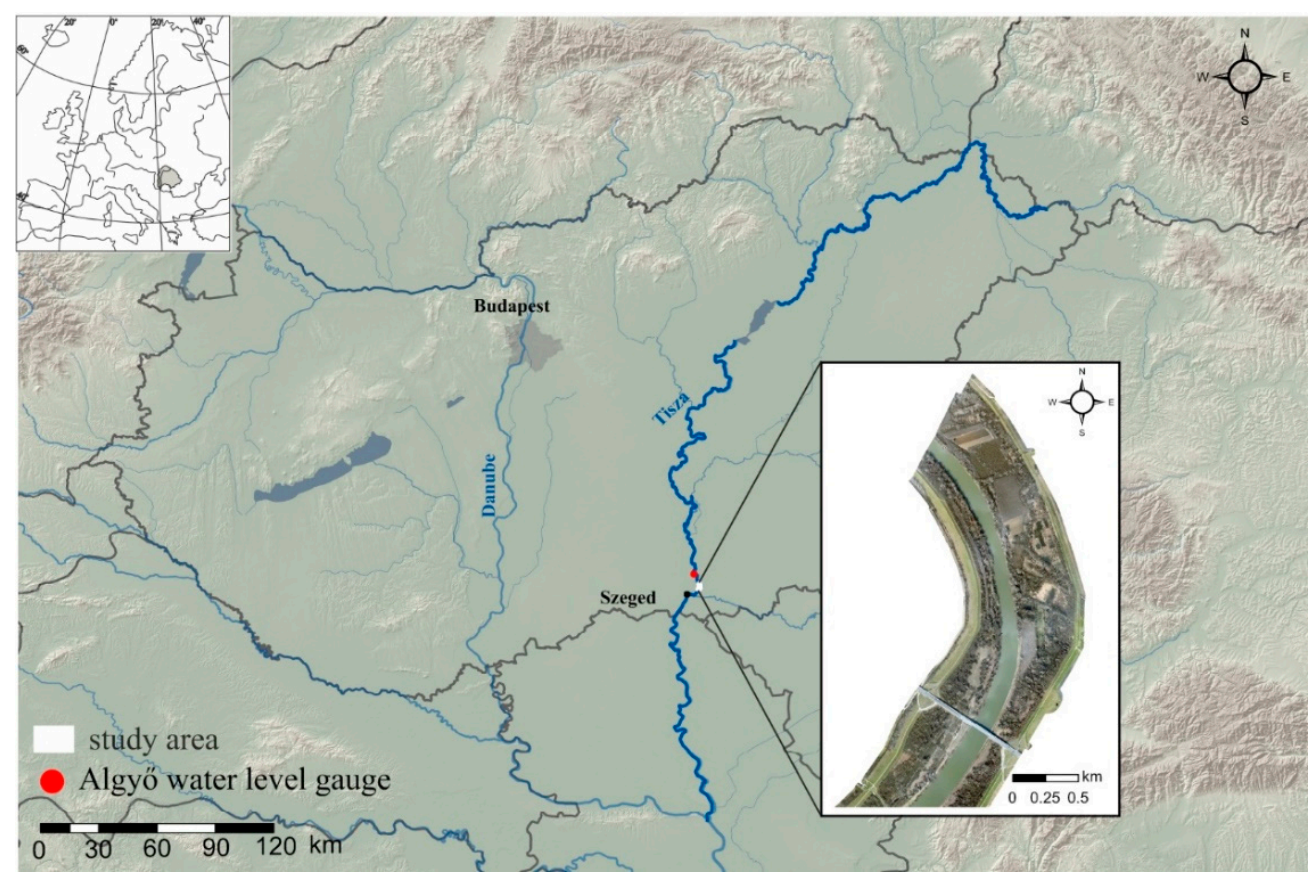

Figure 1. The studied floodplain area is located in the Lower Tisza, Hungary, Central Europe.

\subsection{Vegetation of the Study Area}

The former natural floodplain in the study area was $15 \mathrm{~km}$ wide. In its natural state (based on the First Military Survey made in 1784), a large part (93\%) of the study area was covered by azonal marshes due to half-year-long floods. Meadows, pastures and ploughlands altogether occupied only $2 \%$ of the territory [9]. Forest patches $(5 \%)$ were established only on the elevated riverbanks.

Almost 100 years later (1861-1864: Second Military Survey), the artificial cut-off of the meanders and the construction of the artificial levee system had already started. One bend was cut off in the study area, while the floodplain was narrowed to $600-700 \mathrm{~m}$. The hydro-morphological results of the river training works also affected the vegetation: the proportion of marshy areas has been drastically reduced (to $22 \%$ ), and the former marshes have been replaced by meadows and pastures $(60 \%)$. The area of forests increased $(9 \%)$, and on some meadows and pastures, scattered shrubs (4\%) appeared. The proportion of ploughfields $(5 \%)$ slightly increased.

Two decades later (1881-1884: Third Military Survey), the marshy areas (2\%) had almost disappeared. The meadows and pastures that replaced them gradually became wooded. The proportion of meadows and pastures (55\%) remained similar to the previous one, but the shrubby meadows and pastures (39\%) increased considerably. At the same time, the area of forest patches $(2 \%)$ and cultivated areas $(2 \%)$ has decreased.

On the topographic maps (1979-1985), no marshy areas were indicated, although the water was present in the sand pits (4\%). The area of former open meadows and pastures had decreased $(11 \%)$ due to afforestation (wooded and bushy meadows: $4 \%$ ). The area of ploughlands remained similar (3\%). However, the proportion of woodland $(78 \%)$ has increased considerably; besides, the natural willow-poplar woodland has been replaced mainly by poplar plantations [10].

Towards the end of the 20th century, invasive plants were rapidly expanded with woody stems (e.g., Amorpha fruticosa, Acer negundo), and climbing species (e.g., Vitis riparia, Enchynocystis lobata; Figure 2). The spread of floodplain species was facilitated by record-high floods in 1998-2006 when several meters of water covered the floodplain for 11-72 days [45]. The submerged native species did not tolerate this water cover. Therefore, invasive riparian plants appeared in the empty niches after their death. The Amorpha, in particular, started an explosive spread and created almost impenetrable thickets. Thus, 
by the 2000s, most of the floodplain and planted forests (74\%) in the Lower Tisza were invaded by Amorpha [10]. Nowadays, Amorpha can be observed under every vegetated patch, especially where the canopy is less closed [24].
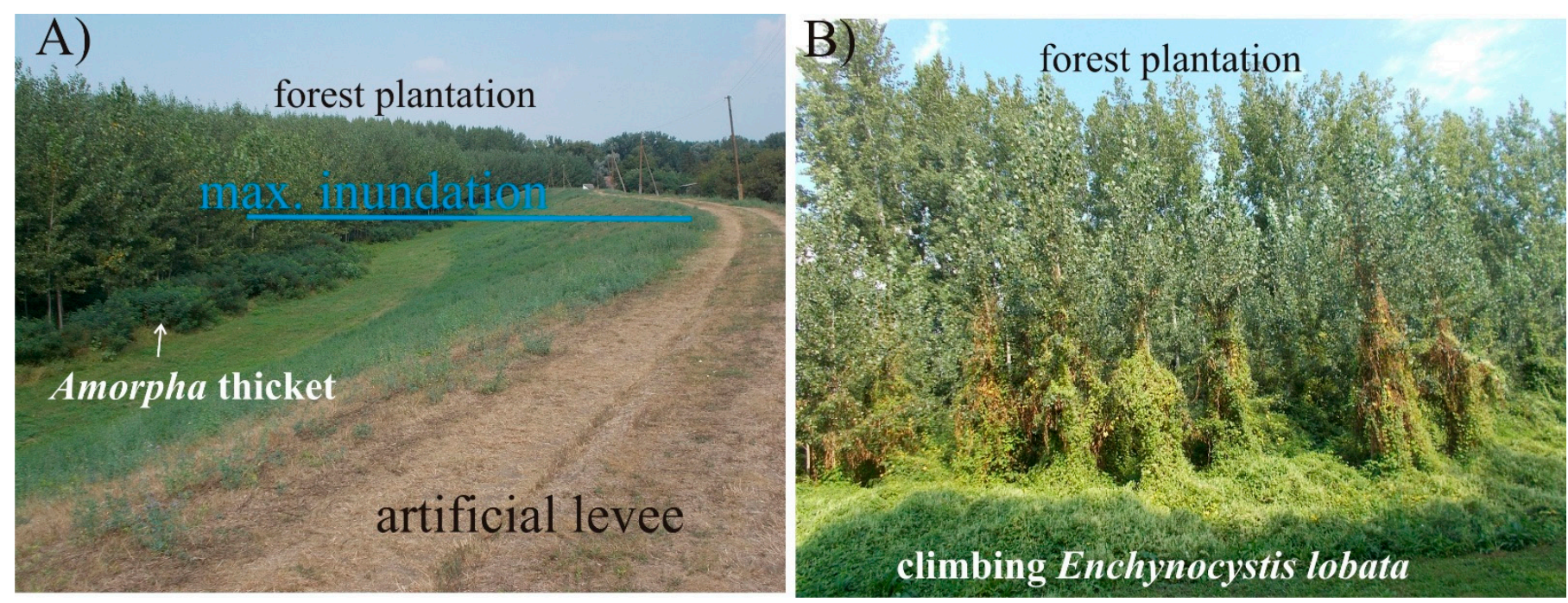

Figure 2. On the confined floodplain, the planted forests are invaded by (A) false indigo (Amorpha fruticosa) bushes and (B) climbing wild cucumber (Enchynocystis lobata).

\subsection{Consequences of Long-Term Land-Use Change in the Study Area}

The gradual change in land use and the spread of invasive plants have significantly increased the vegetation density of the floodplain. The vegetation density in the study area increased by 6.3 -fold (from 0.02 to 0.13 ; [40]). In our previous research [9], we found that Amorpha has played a significant role in higher vegetation density, as it increased the vegetation roughness by $70-85 \%$ in fallow lands, and by $23-34 \%$ in poplar plantations and by $3-26 \%$ in natural riparian forests.

Our former model calculations suggested that vegetation contributed to flood level increase by approximately 15-34 cm [9]. Under the present land-cover conditions, overbank flood flow velocities are very low $(\leq 0.1 \mathrm{~m} / \mathrm{s})$; therefore, flow velocities in the channel are high $(1.0-1.2 \mathrm{~m} / \mathrm{s})$, as the channel must convey a higher proportion of the total flood discharge. Therefore, the channel actively incises $[9,46]$, while suspended sediment is deposited with an accelerating rate on the floodplain [40]. Thus, the accumulation of sediment further reduces the water carrying capacity of the floodplain, as it decreases the volume of the floodplain [40]. Our modelled data [9] suggest that clearing the invasive Amorpha would triple the velocity of water flow in the floodplain (to $0.3 \mathrm{~m} / \mathrm{s}$ ), reduce the incision of the channel and decrease floodplain aggradation, and it would prevent the overlapping of floods caused by slow flood wave translation.

\section{Materials and Methods}

\subsection{Data Source}

The analysis was performed using aerial LiDAR (full-waveform) point cloud (average point density: 9 point $/ \mathrm{m}^{2}$ ), LiDAR-based digital elevation model (resolution: $0.5 \mathrm{~m}$ ) and simultaneous orthophoto survey data (resolution $10 \mathrm{~cm}$ ). EuroSense Ltd. produced the point cloud, the elevation model and the orthophoto; the data are the property of the ATIVIZIG. These surveys were conducted in early spring 2015 before the bud burst; thus, the understory branch structure could be analyzed. The dataset meets the minimum recommended specifications for forest inventory modeling: nominal pulse density of $\geq 3$ pulses $/ \mathrm{m}^{2}, \geq 50 \%$ side lap, and a scan angle within $14^{\circ}$ of nadir [47]. The Fusion 3.8 and ArcMap 10.6.1 software were used for the analysis. Since it is recommended to match the 
spatial resolution to the average canopy diameter [48], the analysis was performed at a $15 \times 15 \mathrm{~m}$ resolution.

Daily stage data were collected at the Algyő gauging station since 01.01.1900. Based on these data, the return periods of floods covering the different vegetation zones (levels) were calculated by applying the Gringorten formula [48]:

$$
\mathrm{T}=\frac{n+0.12}{m-0.44}
$$

where $\mathrm{T}$ is the recurrence interval of floods, $n$ is the total number of years of record, and $m$ is the magnitude or rank of a given flood.

\subsection{Identification of Riparian Vegetation Types}

A decision tree was constructed to identify the different riparian vegetation types based on the calculated descriptive statistical parameters of the point cloud representing the vegetation. The GridMetrics tool of the Fusion program was applied to calculate 55 statistical variables per pixel. The DecisionTreeClassifier algorithm automatically selected those parameters which were used for the decision tree to identify the vegetation types in the area (Table 1).

Table 1. Definition and main characteristics of statistical parameters used to identify various riparian vegetation types.

\begin{tabular}{|c|c|c|}
\hline Parameter & Definition, Calculation & Refers to \\
\hline Canopy relief ratio (CRR) & $\begin{array}{l}\text { The difference between the voxel's (or 3D } \\
\text { pixel) mean and minimum height values of the } \\
\text { points is divided by the difference between the } \\
\text { maximum and minimum height [49]. }\end{array}$ & $\begin{array}{l}\text { The Spatial extent of the canopy: the taller and } \\
\text { wider the canopy, the closer the mean and } \\
\text { maximum values are to each other. }\end{array}$ \\
\hline $\begin{array}{l}\text { Standard deviation of voxel height values } \\
\text { (Elev_stddev) }\end{array}$ & The standard deviation of all points in a voxel. & $\begin{array}{l}\text { Vertical structure and density of the canopy: } \\
\text { the flatter and denser the canopy at a given } \\
\text { level, the more homogeneous the distribution } \\
\text { of points in the cell, and hence the standard } \\
\text { deviation smaller. }\end{array}$ \\
\hline $99 \%$ of the voxel height value (Elev_P99) & $\begin{array}{l}\text { The height value where the percentage of } \\
\text { points representing the cell from the ground } \\
\text { surface reaches } 99 \% \text {. }\end{array}$ & Maximum height of vegetation. \\
\hline $95 \%$ of the voxel height value (Elev_P95) & $\begin{array}{l}\text { The height value where the percentage of } \\
\text { points representing the cell from the ground } \\
\text { surface reaches } 95 \% \text {. }\end{array}$ & Height of vegetation close to maximum. \\
\hline $\begin{array}{l}\text { The skewness of the distribution curve of the } \\
\text { height points of the voxel (Elev_skewness) }\end{array}$ & $\begin{array}{l}\text { The symmetry of the distribution curve } \\
\text { representing the height of the points in } \\
\text { the voxel. }\end{array}$ & $\begin{array}{l}\text { Homogeneity of the canopy. The closer the } \\
\text { value is to zero, the more symmetric the } \\
\text { distribution of points in the voxel. }\end{array}$ \\
\hline
\end{tabular}

In the next step, 40-50 study plots per vegetation type were selected based on the orthophoto for training as cleanly as possible. The selection criteria were that the selected $15 \times 15 \mathrm{~m}$ cell should be homogeneous in vegetation coverage and free of edge effects.

To identify different floodplain vegetation types, a decision tree was constructed in Python using the scikit-learn (0.22.1) library [50]. The decision tree was determined using the Gini index [51] using the DecesionTreeClassifier class of the sklearn.tree module. The Gini index indicates the likelihood of new, random data being misclassified. In the classification steps, the algorithm selects the parameter with the lowest Gini index value. The parameters of the decision tree were set automatically using the GridsearchCV module, taking into account (1) the maximum depth of the decision tree; (2) the minimum number of elements of the decision tree leaves; and (3) the minimum number of elements that determine the further subdivision of the decision tree leaves. To find the ideal parameters of the decision tree algorithm, we used the GridsearchCV class with multiple K-fold cross-validations [52].

Ten-fold cross-validation was used to check the accuracy of the algorithm. Our preliminary results showed that when the decision tree depth was greater than 4.0 , the classification 
accuracy was not significantly improved, but the risk of "overfitting" was significant [53]. Therefore, the decision tree depth was set at 4 in this study. For the learning domain, the accuracy of the decision tree we generated is $92 \%$ based on ten-fold cross-validation.

The vegetation types determined from the decision tree were validated by field surveys and aerial photographs taken with a DJI Phantom III Pro drone (winter 2019). A total of 72 points were photographed in the sample area, aiming to have an equal number of control points per vegetation type. The results of the comparison were summarized in a confusion matrix.

\subsection{Vegetation Density Calculation at Different Canopy Levels}

A detailed analysis of the LiDAR data provides an opportunity to view the density of understory over a large area based on a uniform calculation method. The normalized relative point density (NRD) method $[27,37,38]$ was applied for the vegetation density calculation: the number of points reflected from a given vegetation height zone was divided by the sum of the reflections from the vegetation zone and the reflections from the vegetation zone below. In the study area during floods, the vegetation is submerged up to $5 \mathrm{~m}$, thus the vegetation density in this zone can influence the roughness of the floodplain and flow conditions of a flood. Therefore, the vegetation density between 1 and $5 \mathrm{~m}$ above the surface was analyzed in detail; the calculations were performed for four vertical levels (1-2 $\mathrm{m} ; 2-3 \mathrm{~m} ; 3-4 \mathrm{~m}$ and $4-5 \mathrm{~m})$.

The leafless branch density of the identified vegetation types was calculated over the entire study area by applying a $15 \mathrm{~m}$ cell size in four vertical levels. The median density value $\left(\mathrm{NRD}_{50}\right)$ was calculated for the vertical levels for each vegetation type, as this parameter is less sensitive than the average to outliers due to mixed pixels and classification errors. Besides, the median of leafless branch density of the dense vegetation representing the upper 10th percentile of the dataset $\left(\mathrm{NRD}_{10}\right)$ and the sparse vegetation representing the lower 10th percentile $\left(\mathrm{NRD}_{90}\right)$ was also calculated for each vegetation type to illustrate their density extremes, which usually refers to their understory growth.

To analyze the vertical and horizontal distribution of vegetation density, the understory density values were classified into five groups (1: very sparse understory, 2: sparse, 3: medium, 4: dense, and 5: very dense). As the frequency of density values showed an exponential decrease, the class boundaries were defined based on a geometric distribution. The class boundaries were set at probabilities of no exceedance of 1, 2, 4, 16\% for each vegetation category and height level.

\section{Results}

\subsection{Identification of Vegetation Types}

The young poplar plantation was identified based on its canopy relief ratio (CRR $\leq 0.039)$, which separates well the young trees with low and undeveloped canopy from trees with higher and developed canopy, and also from open surfaces (Figure 3, Table 2). The young poplar plantation was distinguished from open surfaces and Amorpha thickets based on its standard deviation (Elev_stddev $\leq 1.783$ ). Open surfaces and Amorpha thickets were separated based on their height (Amorpha: Elev_P99 $\geq 2.119$ ) and standard deviation value (Amorpha: Elev_stddev $\geq 1.783$ ). Based on the test data, the vegetation types of young poplar plantation, open surface and Amorpha thickets could be filtered completely (Gini index $=0$ ). 


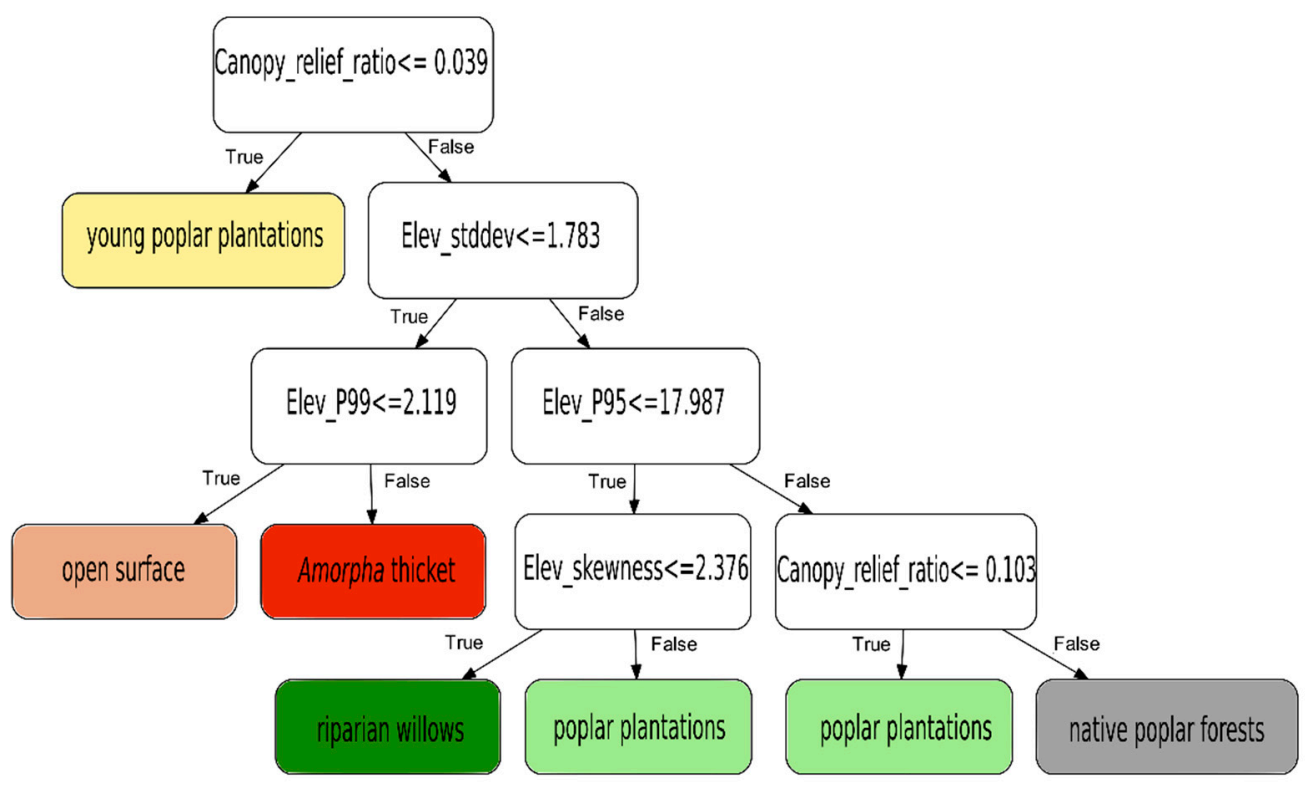

Figure 3. Decision tree created based on selected study plots within the study area.

Table 2. Main characteristics of the identified riparian vegetation types.

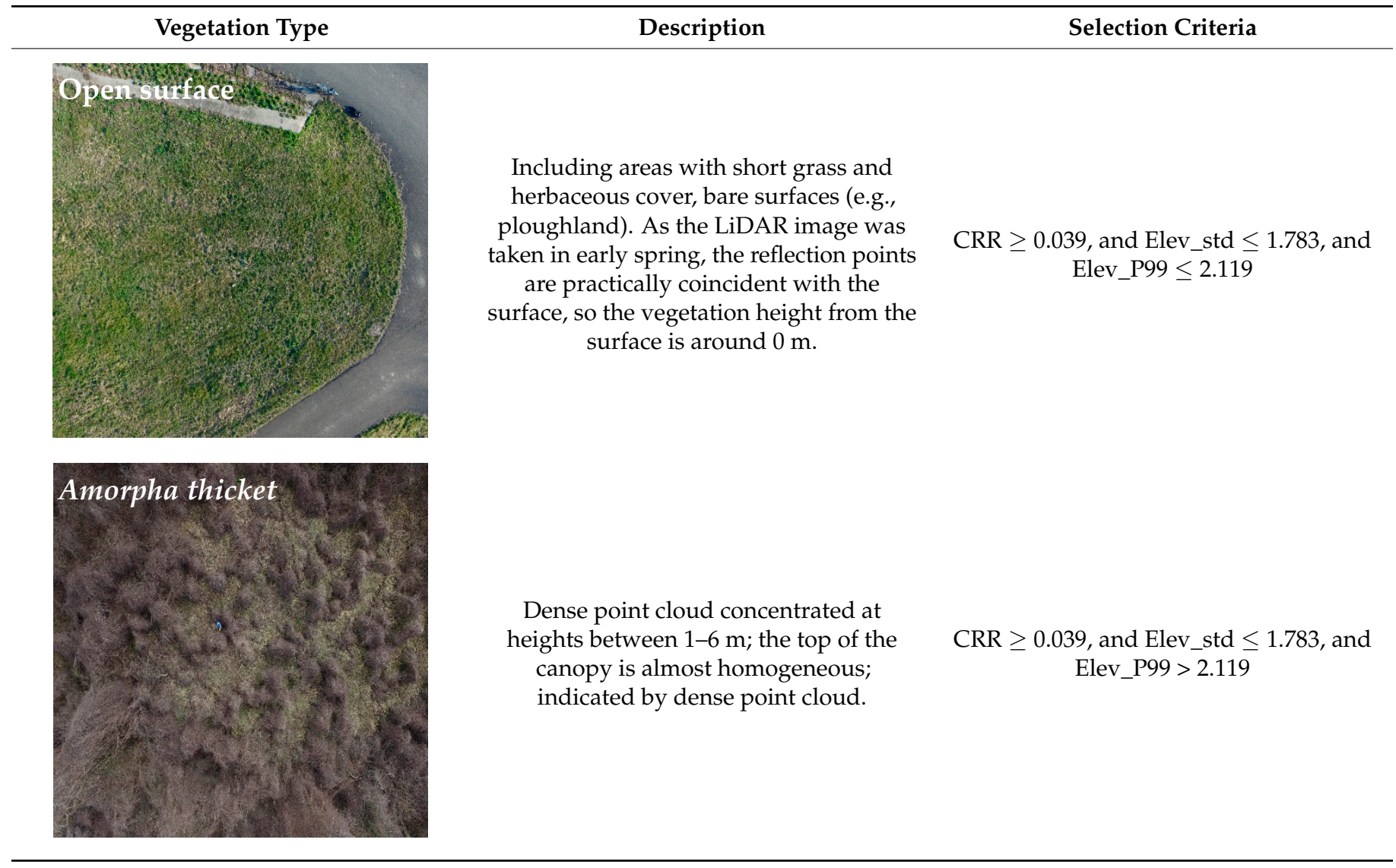


Table 2. Cont.
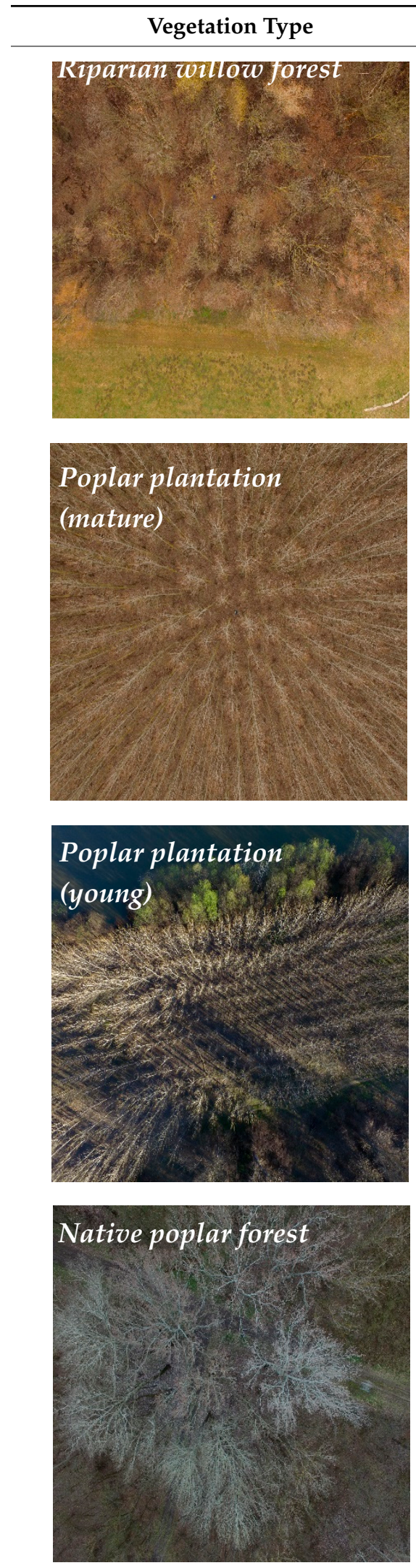

The willows are 16-20 m tall, with a brownish-orange tinge on the orthophoto. Their dense branch structure is highly visible on the point cloud.

Trees are planted in equidistant rows, and the row spacing has increased the scatter of the first rebound (i.e., many points rebounded either from the surface between the poplars or from the top of the canopy). Their sparse branch structure is clearly visible on the LiDAR point cloud.

The young trees are characterised by low height $(>5.6 \mathrm{~m})$, undeveloped branch structure and distant row spacing. This category also includes pixels representing solitary low trees or shrubs.

White poplar (Populus alba) is usually mixed with willows, with low number of individuals. The white poplar has white-greyish tones on the orthophoto and a very distinctive branch structure in LiDAR point cloud.
CRR $>0.039$ and Elev_std $>1.783$ and Elev_P95 $\leq 17.987$ and Elev_skewness $\leq 2.376$

Elev_P95 > 17.987 and CRR $\leq 0.103 \mathrm{OR}$ Elev_std $\geq 1.783$ and Elev_P95 $>17.987$ and $0.039<\mathrm{CRR} \leq 0.103 \mathrm{OR}$

CRR $>0.039$ and Elev_std $>1.783$ and Elev_P95 $\leq 17.987$ and Elev_skewness $>2.376$

$\mathrm{CRR} \leq 0.039$

Elev_std $>1.783$ and Elev_P95 $>17.987$ and CRR $>0.103$ 
In the study area, native poplar forests are characterized by lonely white poplars (Populus $a l b a$ ) rising above lower riparian forest species. Therefore, native poplar forest patches could be identified based on their characteristic height conditions (Figure 3, Table 2). Thus, native poplar forests were distinguished from the riparian willow, and the planted poplar stands by their height (Elev_P95 > 17.987). This screening criterion was not completely clean, as some cells containing taller planted poplars met this criterion. These planted poplar patches could be separated from native poplar forests based on the canopy relief ratio (CRR $\leq 0.103$ ). However, a small proportion of the planted poplars (older, taller individuals) were also sorted on this branch; however, their CRR parameter $(0.039<\mathrm{CRR} \leq 0.103)$ made them distinguishable. Based on the test data, the tall $(\leq 18 \mathrm{~m})$ and old planted poplar and the native poplar forest categories could be screened out completely (Gini index $=0$ ).

In the decision tree, on the true branch of the Elev $\leq 17.987$ criteria, the riparian willow patches and the medium-age and lower planted poplars remained (Figure 3 ). The planted poplars have a slender and columnar canopy and large distances between the individual trees. These characteristics result in asymmetric point distribution in the cells and proportionally less reflectance from the canopy than riparian willows (Table 2). Since the skewness parameter quantifies the asymmetric distribution of points, Elev_skewness (>2.376) reliably separates the planted poplar forests from the riparian willow. Unfortunately, poplars and willows often mix in the floodplain, even within a $15 \times 15 \mathrm{~m}$ cell, and this phenomenon decreases the effectiveness of the classification, but the classification can still be considered as effective (Gini index < 0.16; Figure 3).

The classification accuracy was obtained by comparing the vegetation categories determined in the field with those resulting from the decision tree for 72 cells. The results were recorded in a confusion matrix (Table 3). The classification accuracy of the decision tree is $83 \%$. This value is in line with the literature, as similar results were obtained in areas with dense shrubs and floodplains. For example, in floodplain forests, Saarinen et al. [54] achieved an accuracy of $72.6 \%$ when classifying mobile laser scanner data, while Michez et al. [55] obtained an accuracy of 79.5-84.1\% when classifying drone-derived point clouds. Madsen et al. [56] achieved 86.9-95.2\% classification accuracy when classifying aerial LiDAR data in a bushy area.

Table 3. The validation confusion matrix.

\begin{tabular}{|c|c|c|c|c|c|c|c|}
\hline & & \multicolumn{6}{|c|}{ Based on Decision Tree } \\
\hline & & Open Surface & $\begin{array}{c}\text { Riparian } \\
\text { Willow Forest }\end{array}$ & $\begin{array}{c}\text { Amorpha } \\
\text { Thicket }\end{array}$ & $\begin{array}{c}\text { Native } \\
\text { Poplar Forest }\end{array}$ & $\begin{array}{c}\text { Poplar } \\
\text { Plantation (Young) }\end{array}$ & $\begin{array}{c}\text { Poplar } \\
\text { Plantation (Mature) }\end{array}$ \\
\hline \multirow{6}{*}{ 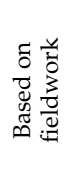 } & Open surface & 0.75 & 0.00 & 0.08 & 0.00 & 0.17 & 0.00 \\
\hline & Riparian willow forest & 0.00 & 0.84 & 0.05 & 0.05 & 0.00 & 0.05 \\
\hline & Amorpha thicket & 0.00 & 0.08 & 0.92 & 0.00 & 0.00 & 0.00 \\
\hline & Native poplar forest & 0.00 & 0.00 & 0.00 & 0.83 & 0.08 & 0.08 \\
\hline & Poplar plantation (young) & 0.00 & 0.00 & 0.17 & 0.00 & 0.83 & 0.00 \\
\hline & Poplar plantation (mature) & 0.00 & 0.00 & 0.00 & 0.18 & 0.00 & 0.82 \\
\hline
\end{tabular}

The classification accuracy of open surfaces $(75 \%)$ is the lowest because some vegetated plots were also defined as open surfaces. For example, some Amorpha thickets (8\%) and young poplar plantations (17\%) were identified as open surfaces. These errors occurred at the boundary of grassy surfaces and forest patches, where the young seedlings and bending low branches caused classification problems. The classification accuracy of riparian willows was $84 \%$, as in some cases, the decision tree classified the riparian willow patches as poplar plantation (5\%), as Amorpha thicket (5\%) or as riparian poplar (5\%). This error originates from several sources: (1) willow forests were cut between the LiDAR acquisition (2015) and validation (2018), and by the time of the field survey the forest clearances were already invaded by Amorpha; (2) these vegetation types are often mixed in nature; and (3) depending on the age of the forest, trees can have very similar canopy height and parameters. The decision tree was the most accurate (92\%) in the case of Amorpha thickets. The error (8\%) originates from the misclassification of willows as Amorpha. However, it should not be considered a serious error, as it occurred in riparian willow patches heavily 
invaded by Amorpha. The classification accuracy of native poplar forests was $83 \%$ since the decision tree classified the riparian poplar patches as either planted poplar $(8 \%)$ or young planted poplar (8\%) in cells where riparian poplar was mixed with planted poplar. The classification accuracy of young poplar plantations was also $83 \%$, as sometimes $(17 \%)$ they were classified as Amorpha thickets. It can be explained by the fact that young, planted poplars have similar parameters (e.g., height, canopy structure) to Amorpha; besides, in plantations, Amorpha can spread quickly in case of mismanagement. The field validation showed that the classification accuracy of the decision tree for mature planted poplar was $82 \%$, as in some cases, they were classified as native poplar forest $(18 \%)$, which their similar height conditions can explain.

\subsection{Spatial Distribution of the Identified Vegetation Types}

The decision tree based on the study plots was applied to the study area (11,656 pixels); thus, the vegetation types were automatically identified on the entire study area (Figure 4).

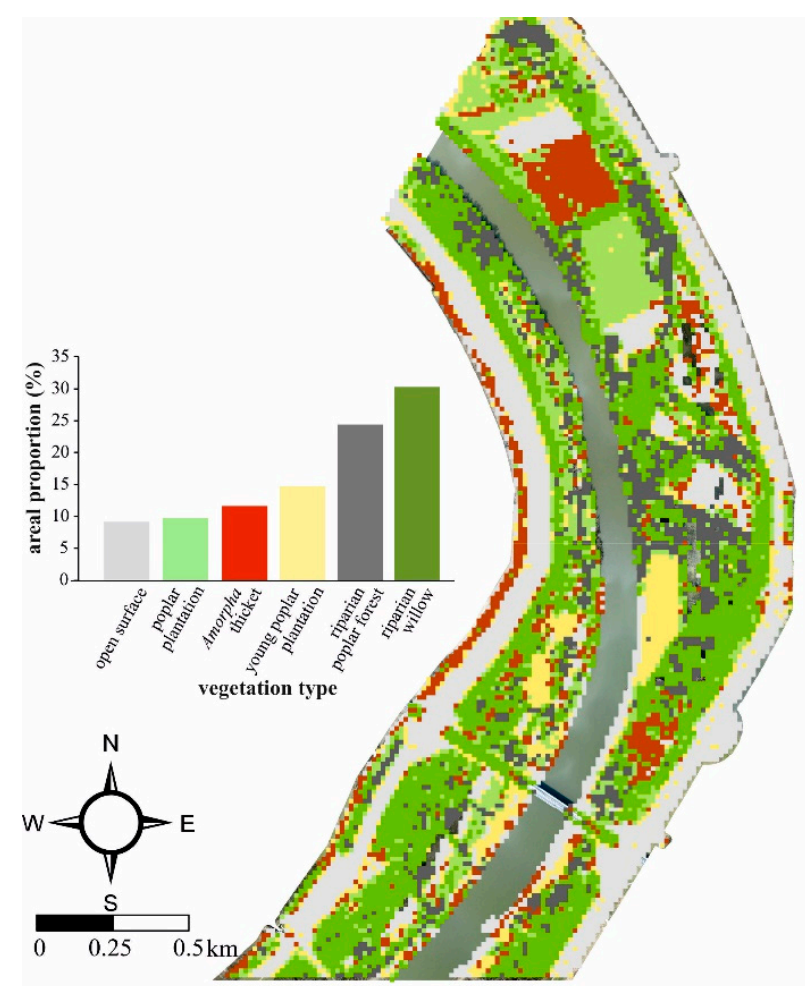

Figure 4. Spatial distribution of various vegetation types identified by machine learning applying the decision tree.

The largest territory is occupied by riparian willow forests $(30 \%, 80$ ha). They are mainly found on the ridges between sand pits in the front of the artificial levees and on the low-lying surfaces. The open surface category $(24 \%, 63 \mathrm{ha})$ is mainly represented by the grass cover of flood protection levees, including some ploughfields and sandpits. A relatively small proportion $(15 \%, 40 \mathrm{ha})$ of the study area is occupied by old poplar plantations, mainly in large parcels. Young poplar plantations cover only a small area $(9 \%$, $23 \mathrm{ha}$ ), though this category also includes sparse patches of young trees and shrubs. From the view of flood conveyance, the most critical vegetation type is the Amorpha thicket $(10 \%$, $25 \mathrm{ha}$ ), which appears mainly on the margin of other vegetation types, on fallow parcels or at forest clearances. It must be noted that in this way, the homogenous Amorpha tickets were identified; however, Amorpha fruticosa also invades the other vegetation types. 


\subsection{Vegetation Density at Different Levels in the Identified Vegetation Types}

Different vegetation types have different understory densities because they (1) are in different habitats, (2) provide different light conditions, and (3) are subject to different management practices and human interference.

In native poplar forests, white poplar (Populus alba) is the characteristic species. Its individuals grow alone, but the species is usually mixed with other trees (e.g., Salix alba, S. fragilis, S. viminalis, Populus nigra). In forest patches, the white poplars are the tallest $\left(\mathrm{H}_{\text {mean }}: 26.5 \mathrm{~m}\right)$, while the other trees growing alongside them are only $15-20 \mathrm{~m}$ high. The white poplars have the largest canopy ( $D_{\text {mean }}: 15 \mathrm{~m}$ ), with a base at $10-12 \mathrm{~m}$ above the ground. The median NRD density decreases linearly $(r=0.97)$ from the surface to the top of the canopy (Figure 5). Usually, in the $1-2 \mathrm{~m}$ level the $\mathrm{NRD}_{50}$ density value is 0.021 . However, it is only 0.01 in the upper zones of the canopy $(>20 \mathrm{~m})$. In voxels with sparse understory vegetation $\left(\mathrm{NRD}_{90}\right)$, the density $(0.007)$ is very low above the surface $(1-2 \mathrm{~m})$, and it reaches its highest value (0.017) between $16-17 \mathrm{~m}$. In native poplar forests with dense understory $\left(\mathrm{NRD}_{10}\right)$, the NRD density value is the highest $(0.12)$ in the $1-2 \mathrm{~m}$ zone, thus 15 times greater than in the same level with sparse understory patches. Towards the higher levels of the canopy, the density decreases exponentially until the $9-10 \mathrm{~m}$ zone $(0.006)$, then above $10 \mathrm{~m}$, the decrease becomes moderate and linear. In native poplar forests patches with extremely dense understory, NRD values in the lower vegetation zones (1-3 m) can reach $0.3-0.4$.

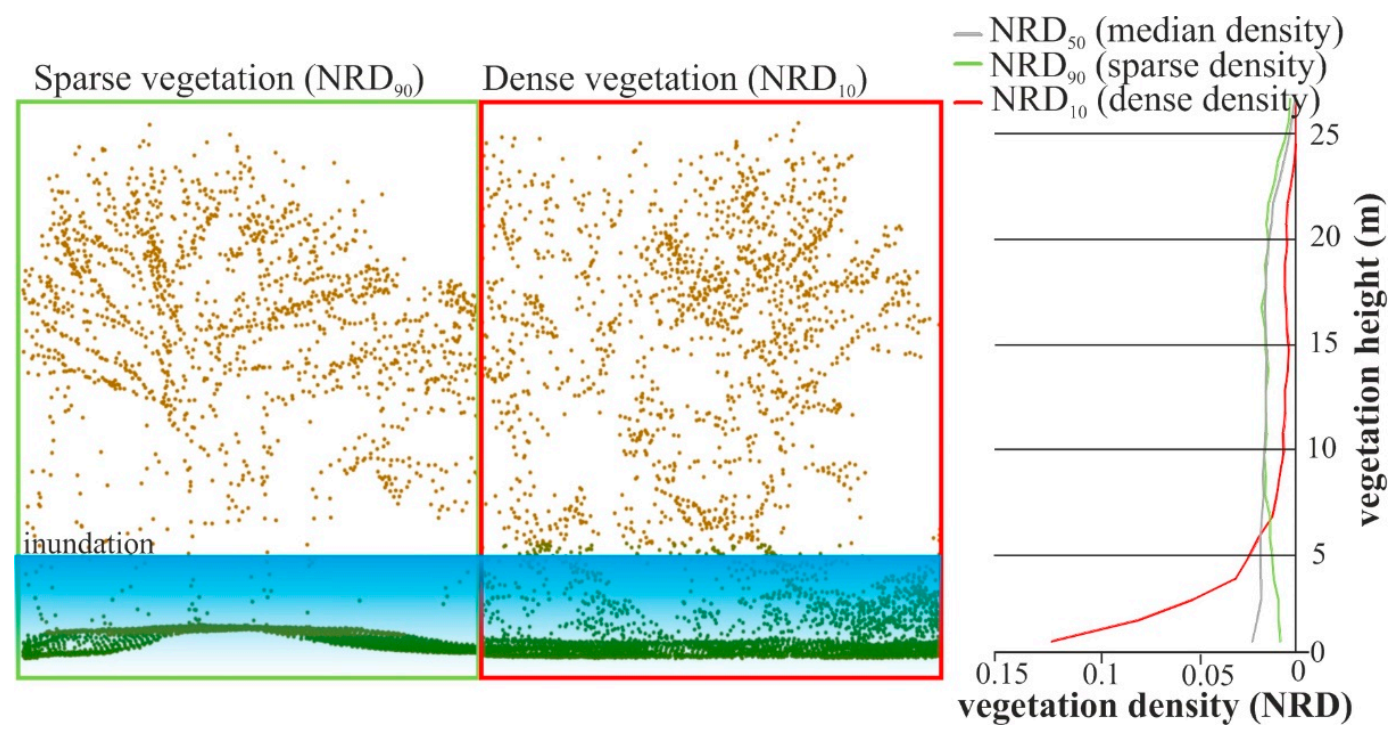

Figure 5. LiDAR point distribution in voxels with sparsely and densely vegetated native poplar forests, and characteristic vertical distribution of their vegetation density.

The riparian willow forests mainly consist of willow species (e.g., Salix alba, S. fragilis), and they have lower height $\left(\mathrm{H}_{\text {mean }}: 17.6 \mathrm{~m}\right)$, smaller canopy diameter $\left(\mathrm{D}_{\text {mean }}: 5-7 \mathrm{~m}\right)$ and lower canopy base (5-6 m) than the native poplar forests. The number of trees per unit area in the floodplain willow forests is greater than in the native poplar forests; thus, the trees create denser forests. The median value of vegetation density $\left(\mathrm{NRD}_{50}\right)$ decreases linearly $(\mathrm{r}=0.93)$ towards the top of the canopy (Figure 6), although the decrease is more rapid at zones above $10 \mathrm{~m}$. The vegetation density in sparse willow forests $\left(\mathrm{NRD}_{90}\right)$ is the highest near the top of the canopy (11-12 m zone: 0.024$)$, whilst lower NRD values (0.01-0.02) are near the ground (1-4 m) and above $12 \mathrm{~m}$, where the smaller and thinner branches are. In riparian willow forests with dense understory $\left(\mathrm{NRD}_{10}\right)$, the vegetation density in the $1-2 \mathrm{~m}$ zone is (0.17), thus nearly 17 times higher than at the same level of sparse understory willows. However, in very dense willow forest patches near the surface (1-2 m), the NRD value can reach 0.3 . In riparian willow forests with dense understory $\left(\mathrm{NRD}_{10}\right)$ between 
2 and $11 \mathrm{~m}$, an exponentially decreasing trend in vegetation density is observed, while in the higher zones (12-20 m), the rate of decrease in NRD density is lower, and it follows a linear trend.

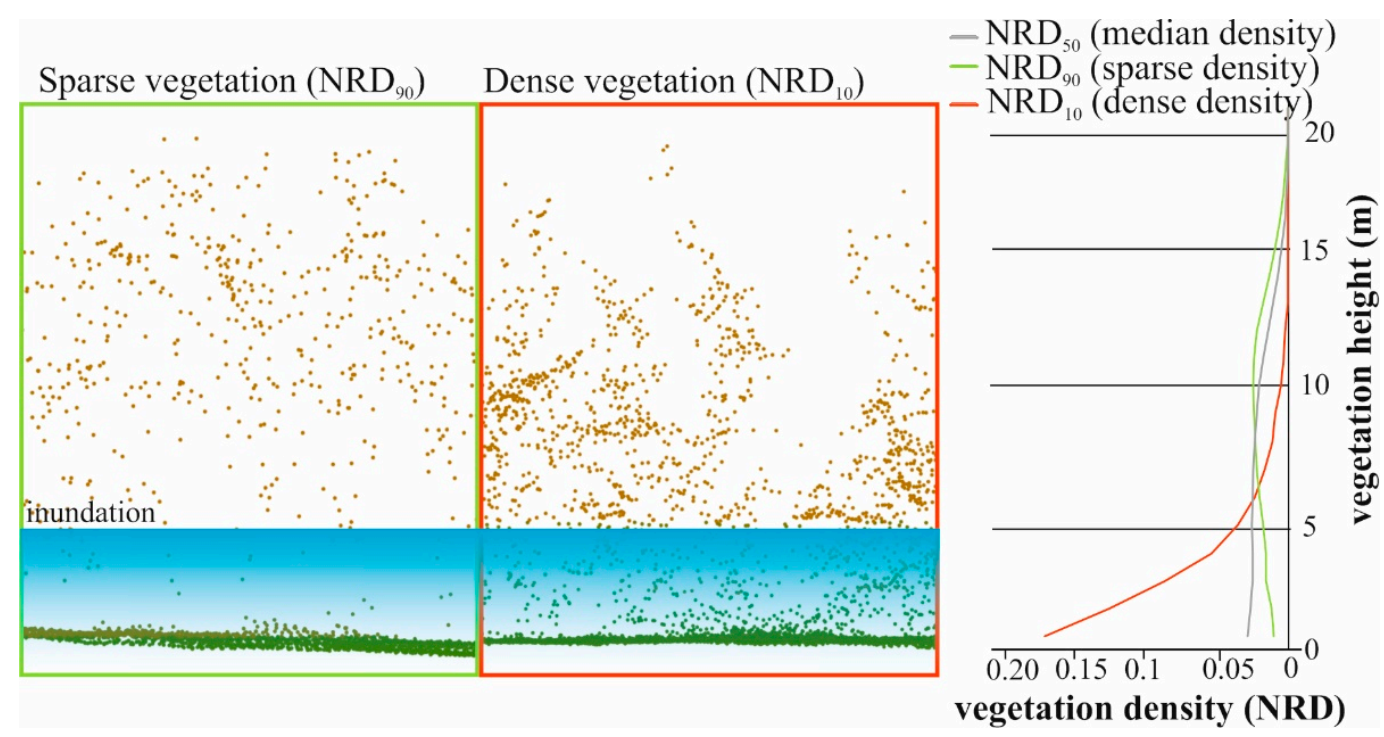

Figure 6. LiDAR point distribution in voxels with sparsely and densely vegetated riparian willow forests, and characteristic vertical distribution of their vegetation density.

The poplar plantations have almost homogeneous stands. The height of the mature trees $\left(\mathrm{H}_{\text {mean }}: 18.5 \mathrm{~m}\right)$ is almost the same as that of the riparian willow forests, but the diameter of their canopies is only $3-5 \mathrm{~m}$. The base of the narrow canopy is $5-8 \mathrm{~m}$ above the ground, depending on the individual's height. The median NRD density is 0.024 at $1-2 \mathrm{~m}$ (Figure 7), and it decreases linearly to 0.004 at $14-15 \mathrm{~m}$.

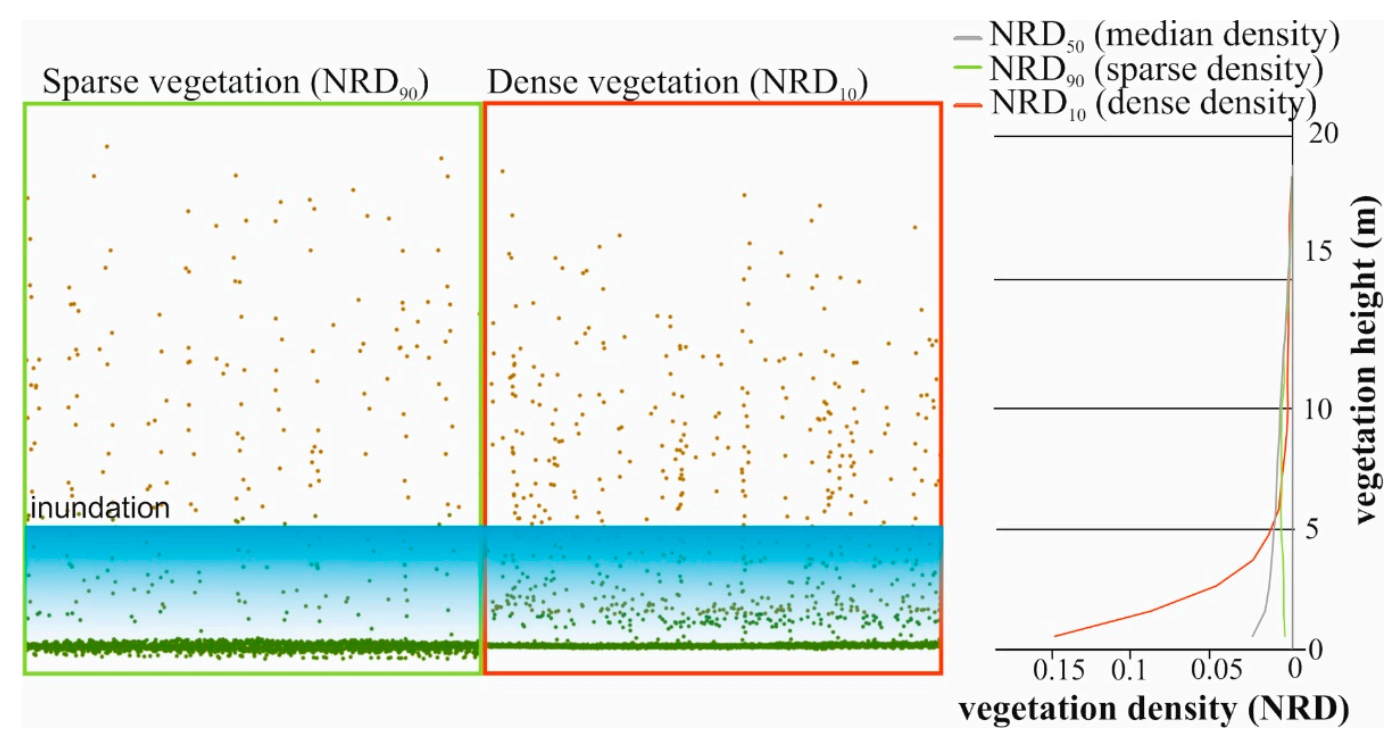

Figure 7. LiDAR point distribution in voxels with sparsely and densely vegetated mature poplar plantations, and characteristic vertical distribution of their vegetation density.

In mature planted poplars with sparse underwood $\left(\mathrm{NRD}_{90}\right)$, the vegetation density is getting higher (from 0.004 to 0.007 ) towards the $7-8 \mathrm{~m}$ zone, and then above $8 \mathrm{~m}$, it linearly decreases. In mature planted poplar trees with dense understory $\left(\mathrm{NRD}_{10}\right)$, the median value of the vegetation density $(0.14)$ in the $1-2 \mathrm{~m}$ zone is 30 times higher than the value 
in the same zone of poplar plantations with sparse understory (0.004). In pixels with the densest vegetation, NRD values near the surface (1-2 m) can be as high as 0.25-0.3. In zones above $2 \mathrm{~m}$, an exponentially decreasing trend in vegetation density is observed up to the 7-8 $\mathrm{m}$ zone (0.06), followed by a decrease from the 7-8 $\mathrm{m}$ zone to the top of the canopy.

Young poplar plantations have relatively small trees $\left(\mathrm{H}_{\text {mean }}: 9 \mathrm{~m}\right)$, with a narrow canopy ( $\mathrm{D}_{\text {mean }}: 1 \mathrm{~m}$ ) and low canopy base (3-4 m; Figure 8$)$. The median value of NRD density is only 0.007 at the $1-2 \mathrm{~m}$ zone, and it decreases linearly $(r=0.94)$ with height. Young poplar plantations usually have sparse understory $\left(\mathrm{NRD}_{90}\right)$ or no understory at all. However, even if they have dense understory $\left(\mathrm{NRD}_{10}\right)$, the median value of vegetation density at $1-2 \mathrm{~m}$ is only 0.06 , indicating the lack of understory.
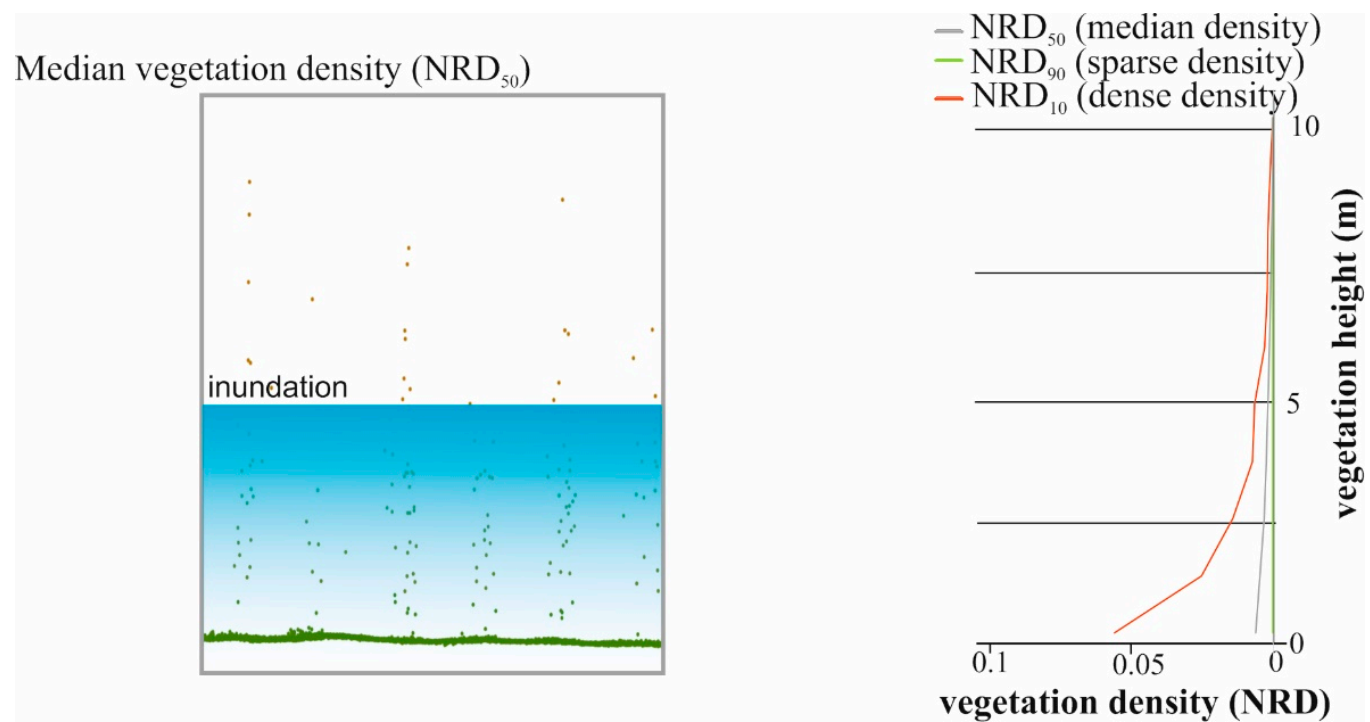

Figure 8. LiDAR point distribution in voxels with sparsely and densely vegetated young poplar plantations, and characteristic vertical distribution of their vegetation density.

The invasive Amorpha fruticosa bushes form almost homogeneous stands on fallow lands or in the area of forest clearances. The Amorpha is light-demanding and overgrows under favorable conditions [56]. The average height of the Amorpha thickets is only 4-5 m (Figure 9). They do not develop a mature canopy, as the branches gradually get thinner from the ground. The median value of NRD density is the greatest in the near-ground level (1-2 m zone: 0.051), and it gradually decreases upwards (e.g., 2-3 m zone: 0.032 in the), and then decreases rapidly at the 4-5 m zone, (to 0.017). In sparse Amorpha thickets (NRD90), the NRD density value reaches its maximum in the 2-3 m zone (0.013), and above this zone, the NRD density is decreasing (to 0.01). In dense Amorpha stands ( $\left.\mathrm{NRD}_{10}\right)$, the NRD density (0.23) at the 1-2 $\mathrm{m}$ level is 30 times greater than in the sparse stands (0.011). The maximum value of NDR density in the densest Amorpha thickets reaches 0.5-0.6 in the 1-2 $\mathrm{m}$ zone, and it exponentially decreases to 0.016 .

\subsection{Classification of Voxels Based on Their Vegetation Density in the 1-5 m Level}

Each vegetation type was divided into five classes based on the vegetation density (Figure 10). The vertical distribution of these density classes was analyzed just in the lower (1-5 m) vegetation zone prone to flooding. Based on this analysis, those vegetation types can be identified, which have the densest understory and probably the most infected by invasive species; thus, their management should be reconsidered. 


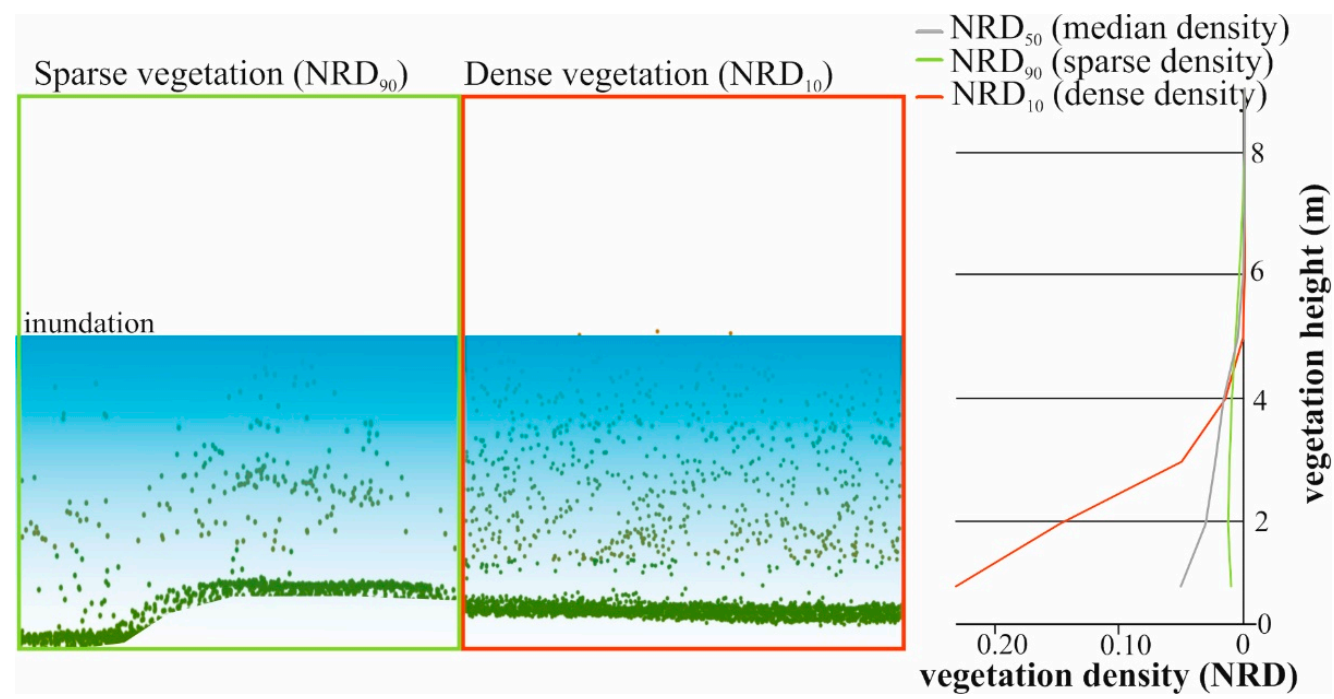

Figure 9. LiDAR point distribution in voxels with sparsely and densely vegetated Amorpha thickets, and characteristic vertical distribution of their vegetation density.

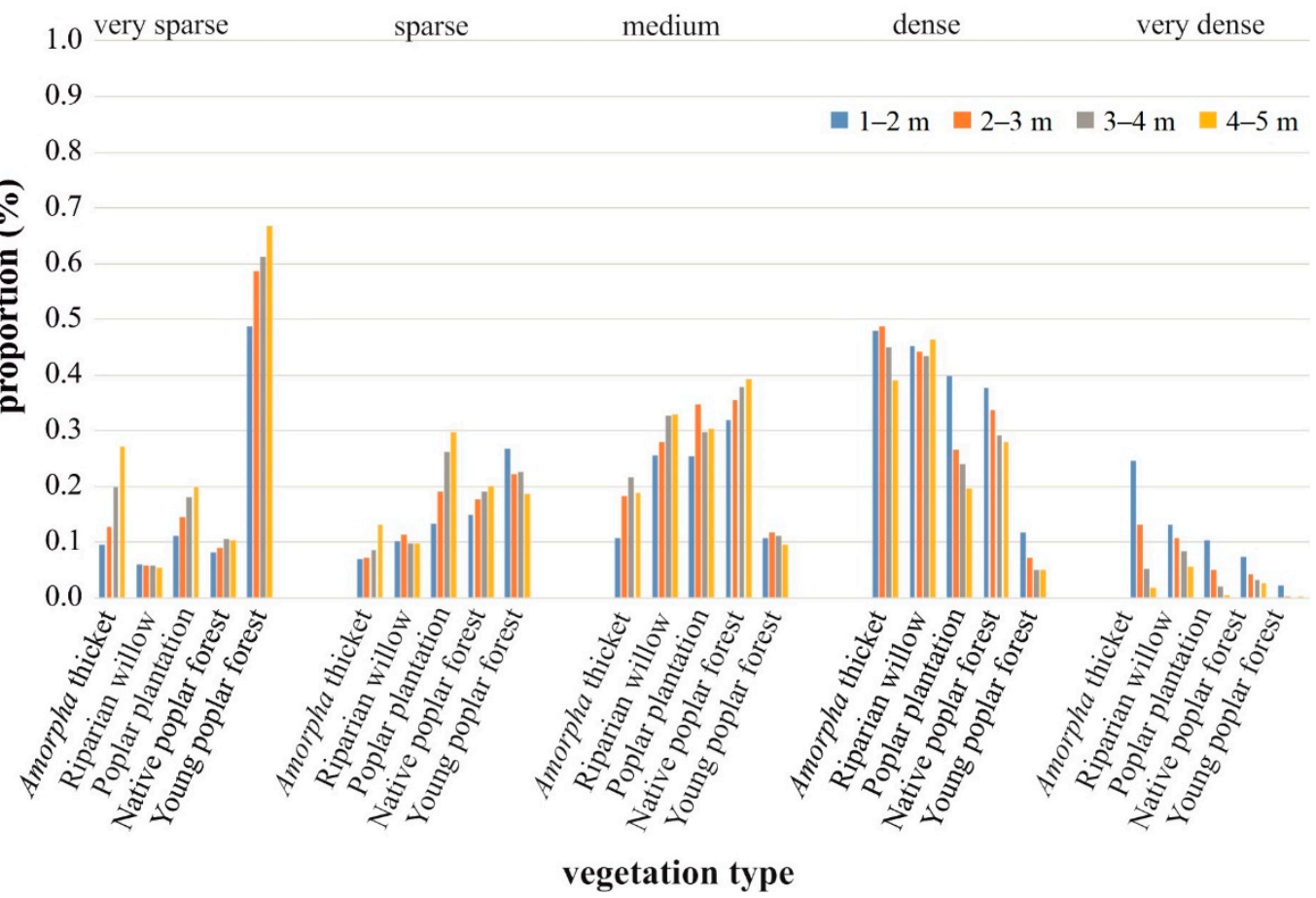

Figure 10. Distribution of various density classes at the identified vegetation types and considering the height zones of the understory.

The very sparse vegetation is the best from the point of view of flood conveyance. It is present in $21 \%$ of voxels. It is the most common in all height zones of young poplar plantations. The very sparse underwood class is the least characteristic in riparian willow forests. In the case of very sparse Amorpha thickets, the higher canopy zones are characterized by a sparser branch structure because the uppermost branches (at the 4-5 m zone) are tiny as the bush reaches its maximum height.

In the flood conveyance zone (1-5 m), the sparse vegetation class (16\% of the voxels) is the most typical in mature poplar plantations, and especially at their upper (4-5 m) zone. However, the sparse understory is also common in young poplar plantations, but contrary to other classes, it is the most frequent at the 1-2 $\mathrm{m}$ zone. 
The medium density vegetation class covers $25 \%$ of voxels. Native poplar forests are the most abundant in this category, though this class is also typical in the riparian willow forests and mature planted poplar forests. Medium-density understory is the least common in the case of young poplar plantations.

The dense understory vegetation class is the most characteristic in the study area (31\% of the voxels). The most common vegetation type within this density class is Amorpha thicket, with most voxels occurring at the lower (1-3 m) levels. Most of the riparian willow forests dense understory vegetation is typical in all levels. The dense understory is not common in young poplar plantations.

From the view of flood conveyance, the least favorable is the very dense vegetation in the 1-5 m levels. Very dense vegetation voxels are only on $6 \%$ of the study area. In this class, Amorpha thickets are the most common, especially since their lower levels are dense. Some of the riparian willow forests also have a very dense understory; however, it is less common in the case of the other vegetation types.

It is interesting to note that the dense and very dense understory vegetation is the most common near to the surface (1-2 m zone) in the case of all vegetation types, and their proportion is gradually decreasing in the higher zones. This suggests that the very dense category developed mainly in the various vegetation types because the seedlings form dense stands. Later these seedlings grow thinner depending on the species type and environmental conditions. On the contrary, the very sparse and sparse understory vegetation is more common in the higher levels. These suggest that the lower overbank floods have to flow through denser vegetation; thus, they face greater friction than the peak floods.

\subsection{Vertical and Horizontal Distribution of Various Density Classes of the Vegetation Types}

The primary hydrological function of lowland confined floodplains with low slopes is to ensure unhindered drainage of overbank floodwaters. Therefore, the spatial (horizontal and vertical) distribution of cells with high vegetation density is essential. Thus, the distribution of vegetation density in the 1-5 m zone (i.e., up to the height of the artificial levees) was analyzed in detail. Since floods have various heights and recurrence intervals, it was evaluated how the understory density might influence them. Based on the daily stage data of more than 120 years, the annual flood recurrence interval and their probabilities covering the vegetation zones (1-5 m) were calculated using the Gringorten formula (Table 4).

Table 4. Recurrence interval and annual probability of floods submerging the vegetation height zones up to the level of the artificial levees.

\begin{tabular}{cccc}
\hline $\begin{array}{c}\text { Vegetation Zone } \\
\text { Covered by Flood }\end{array}$ & $\begin{array}{c}\text { Flood Water Level } \\
\text { Covering the } \\
\text { Zone(m a.s.l.) }\end{array}$ & $\begin{array}{c}\text { Flood Recurrence } \\
\text { Interval (Year) }\end{array}$ & $\begin{array}{c}\text { Flood Annual } \\
\text { Probability }\end{array}$ \\
\hline $1-2 \mathrm{~m}$ & 80.5 & 2 & 0.51 \\
$2-3 \mathrm{~m}$ & 81.5 & 3 & 0.32 \\
$3-4 \mathrm{~m}$ & 82.5 & 9 & 0.11 \\
$4-5 \mathrm{~m}$ & 83.5 & 25 & 0.04 \\
\hline
\end{tabular}

The recurrence interval of floods covering the vegetation's lowermost (1-2 m) zone is two years; thus, floodplain vegetation in this zone interacts with the flood flow relatively frequently, changing its velocity and influencing its duration (Figures 11 and 12, Table 5). Within this zone, the Amorpha thickets have the highest density (NRD median: 0.051), while the riparian willow forests, the mature poplar plantations, and native poplar forests have a considerably lower density ( $\mathrm{NRD}_{\text {median }}$ : 0.021-0.029). The lowest vegetation density value $\left(\mathrm{NRD}_{\text {median }}\right.$ : 0.006$)$ was measured in young poplars plantations, which are artificially cleared and maintained periodically. The difference between the density of the Amorpha thickets and cultivated poplar plantations is 9-fold. The dense (36\%) and very dense vegetation patches (12\%) in the 1-2 m zone occupy almost half of the study area (48\%). 
These patches are common everywhere; however, they can even effectively influence the flow conditions along the channel and in the southern part of the study area (near the bridge).

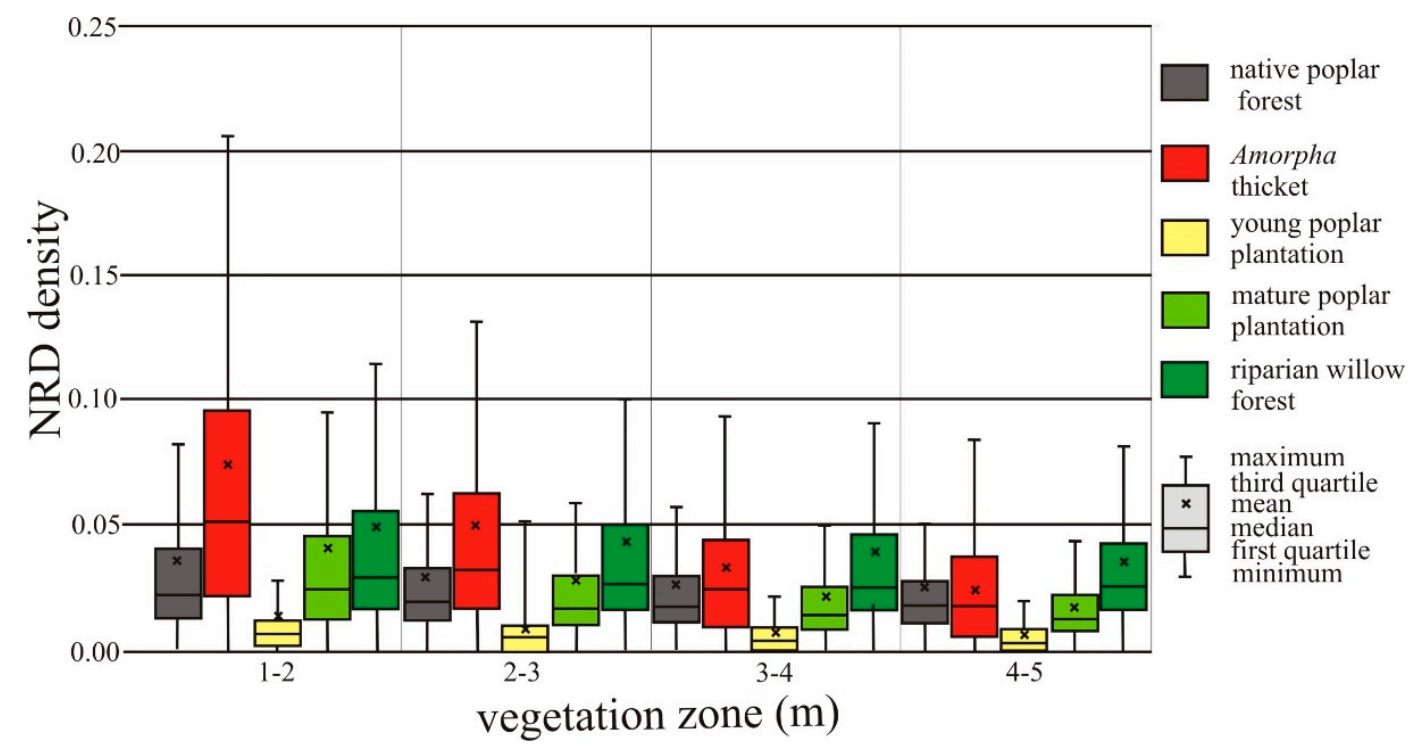

Figure 11. The NRD density in vegetation categories at different zones of the vegetation.

\section{1-2 $\mathrm{m}$ vegetation zone $\quad$ 2-3 $\mathrm{m}$ vegetation zone $\quad 3-4 \mathrm{~m}$ vegetation zone $\quad 4-5 \mathrm{~m}$ vegetation zone}

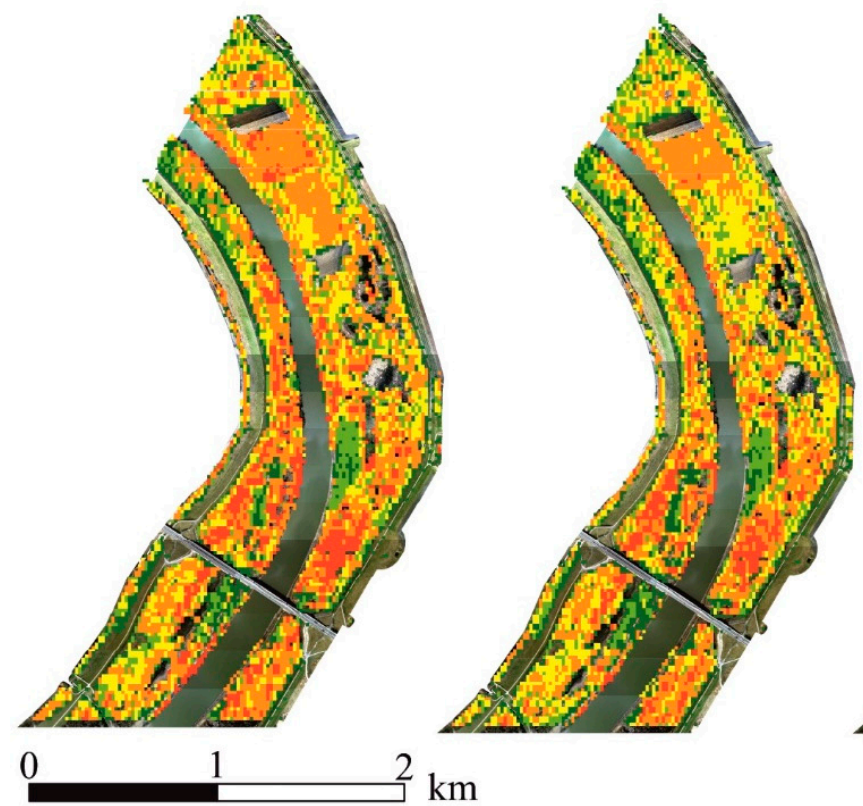

$\mathrm{km}$
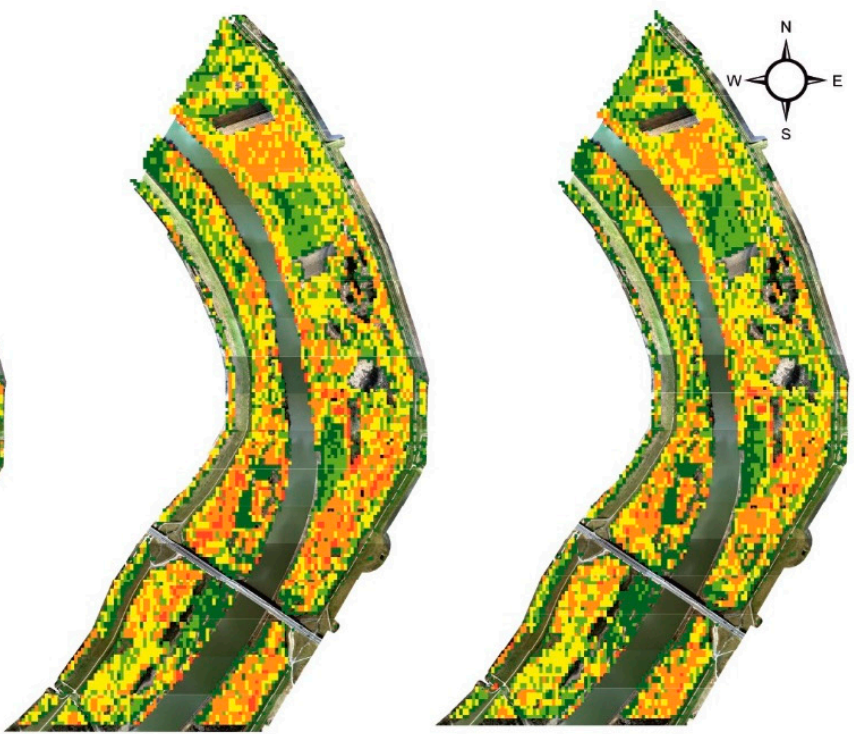

very sparse $\square$ sparse $\square$ medium $\square$ dense $\square$ very dense

Figure 12. Spatial distribution of various density classes at the four vegetation zones. 
Table 5. Frequency (\%) of vegetation density categories in the different flooded height zones.

\begin{tabular}{ccccc}
\hline Vegetation & \multicolumn{3}{c}{ Frequency of Density Categories at Vegetation Height Zones } \\
\cline { 2 - 5 } Density & $\mathbf{1 - 2} \mathbf{~ m}$ & $\mathbf{2 - 3} \mathbf{~ m}$ & $\mathbf{3 - 4} \mathbf{~}$ & $\mathbf{4 - 5} \mathbf{~ m}$ \\
\hline very sparse & 17 & 20 & 23 & 26 \\
sparse & 14 & 16 & 17 & 18 \\
medium & 21 & 32 & 27 & 26 \\
dense & 36 & 7 & 29 & 28 \\
very dense & 12 & 100 & 100 & 2 \\
Total & 100 & & & 100 \\
\hline
\end{tabular}

The higher, $2-3 \mathrm{~m}$ zone of the vegetation is flooded just in every three years. In this zone, the Amorpha thickets create the most significant obstacle ( $\left.\mathrm{NRD}_{\text {median }}: 0.032\right)$ for the flood wave. However, the riparian willow patches also create dense stands $\left(\mathrm{NRD}_{\text {median }}: 0.026\right)$. The native poplar forest $\left(\mathrm{NRD}_{\text {median }}: 0.019\right)$ and the mature poplar plantations ( $\mathrm{NRD}_{\text {median }}$ : 0.016$)$ provide slightly better conditions for flood conveyance. The best flow environment is provided by the young poplar plantations ( $\mathrm{NRD}_{\text {median }}$ : 0.005), as their density is lower by $82-85 \%$ than of the willow forests and Amorpha thickets. In this zone, the proportion of patches with dense and very dense vegetation decreased (38\%). Their spatial distribution is similar to that of the densely vegetated voxels in the $1-2 \mathrm{~m}$ zone; just in the northern half of the study area, the dense vegetation is less common, though in the southern half of the study area (around the bridge) they are still common.

The next zone (3-4 m) could be flooded just by nine-year return-interval floods. In this zone, the proportion of dense and very dense vegetation understory decreases to $33 \%$, as patches replace them with sparse or very sparse vegetation (40\%). At this vegetation zone, the density of Amorpha thickets (NRD median: 0.024 ) decreases by $25 \%$ compared to the previous zone. Similarly, dense understory developed in this level in riparian willows (NRD median: 0.025). Considerably lower values characterize the native poplar forests $\left(\mathrm{NRD}_{\text {median }}: 0.017\right)$ and the mature poplar plantations ( $\left.\mathrm{NRD}_{\text {median: }}: 0.014\right)$. Still, the most favorable flow conditions are provided by the sparse young poplar plantations $\left(\mathrm{NRD}_{\text {median }}\right.$ : 0.003). In this zone, the low vegetation density patches appear along the channel, creating more favorable conditions for flood conveyance.

The 250 year-return period floods cover the uppermost flooded $(4-5 \mathrm{~m})$ zone. The riparian willow patches $\left(\mathrm{NRD}_{\text {median }}: 0.025\right)$ are the densest in this zone, followed by natural poplar forests and Amorpha thickets with the same branch density ( $\mathrm{NRD}_{\text {median: }}$ 0.017). Low vegetation density characterizes the mature and young poplar plantations $\left(\mathrm{NRD}_{\text {median }}\right.$ : 0.012 and 0.002 , respectively). In this zone, the proportion of dense and very dense vegetation understory decreased further on (to $30 \%$ ), and the very sparse and sparse patches became dominant $(44 \%)$. In this zone, the low-density understory vegetation provides the most favorable conditions for flood flow, and the considerable vegetation barriers along the banks and in the southern part of the study area are no longer apparent.

\section{Discussion}

Over the large floodplain areas, determining vegetation types and their density by field surveys is time-consuming and often not feasible due to the terrain conditions. However, for proper floodplain management and precise flood modelling, it is necessary to provide up-to-date information on vegetation types and understory vegetation. It is especially important in densely vegetated floodplains with low slopes, where vegetation can considerably influence the flood conveyance. The Central European rivers have narrow, confined floodplains with very low slopes; thus, unobstructed flood conveyance should be achieved for successful flood management. It might be contradictory, as in many countries, the storage of floodwaters is the way of mitigation of flood risk downstream [4,13-15]. However, as here floods have a very low slope and long duration, the main aim is to shorten the height and length of floods to decrease flood risk. 
The former studies described high density of the riparian vegetation, however, based on a field survey of a limited number of plots $[9,10,23,40,45]$. Our study proved that even in almost impenetrable forests or shrubbery, the vegetation types and their branch density could be determined accurately. Applying a decision tree and its validation enabled us to automatically identify various riparian vegetation categories based on the statistical analysis of the point cloud of an airborne LiDAR survey representing the vegetation. The combination of various calculations allowed us to quantify the vegetation types based on their density, considering various elevation zones. The determination of normalized relative point density (NRD) values from the LiDAR point cloud proved to be applicable in the highly invaded riparian vegetation of the Tisza River. Based on the spatial analysis of density values, vegetation patches that impede flood flow were identified at different flood depths. It can help to plan vegetation management in large areas accurately and to monitor it by the authorities.

\subsection{Riparian Vegetation Types and Their Understory Density in the Study Area}

The proportion of riparian forests in the studied confined floodplain is $80 \%$, which is the highest value along the Lower Tisza since the first spatial data from the late 18th century [8]. Unfortunately, these forests are highly invaded by invasive species [23,24], which is an unfavorable phenomenon from the point of view of floodplain roughness, as the rigid stems of the invasive plants can effectively decrease the flow velocity and can increase flood height $[9,10]$.

In the studied floodplain section along the Lower Tisza, the majority of the understory of the forests $(62 \%)$ belong to at least the medium density category at the flood conveyance zone (1-5 m, up to the level of the artificial levees). Besides, 37\% of the forests have dense or very dense understory, which probably effectively hinder flood conveyance. Our field surveys confirmed that most of the medium to very high-density classes are created by invasive plant species (e.g., Amorpha fruticosa, Acer negundo), which dominate the understory of forests and invade fallow lands. Although Sándor [10] and Delai et al. [23] came to a similar conclusion based on their field survey of a limited number of points, the present study confirmed that the entire floodplain is invaded. Besides, by applying the presented methodological steps, the spatial distribution of the dense vegetation patches could be determined all over the study area with great temporal and spatial resolution.

The least invaded natural vegetation type in the study area is the natural poplar forest (covering $16 \%$ of the study area). The most characteristic species of natural poplar forests is the white poplar (Populus alba), which usually stands alone or in small groups, and it is usually mixed with other trees (e.g., Salix alba, S. fragilis, S. viminalis, Populus nigra). Among the natural woody vegetation types, the understory vegetation density under natural poplar forest is the most ideal for flood conveyance, but less favorable than the properly managed poplar plantations. In the natural poplar forests, the vegetation density $\left(\mathrm{NRD}_{50}\right)$ in the potentially flooded $(1-5 \mathrm{~m})$ zone range from 0.21 to 0.17 , and $32 \%$ of them were classified as dense and only $4 \%$ as very dense. As the white poplars are the tallest trees $\left(\mathrm{H}_{\text {mean }}: 26.5 \mathrm{~m}\right)$ and the other trees growing alongside them are only $15-20 \mathrm{~m}$ high, their dense canopy does not provide ideal light conditions for understory vegetation, it is especially unfavorable for the heliophylous Amorpha [57,58]. Besides, white poplars taller than $25 \mathrm{~m}$ are 40-50 years old (their maximum age is 150-200 years; [57]), thus in these old stands, the light conditions have been insufficient for the growth of various understory plants for a while. Therefore, in the lack of disturbance, the natural poplar forests are invaded by invasive species only to a limited extent.

The natural riparian willow forests occupy the largest territory (39\%) of the study area. The height $(17.6 \mathrm{~m})$ and width $(5-7 \mathrm{~m})$ of the canopy of the willow species (Salix sp.) are smaller than those of white poplars; however, their number is larger in a unit area; besides, they are usually highly invaded by Amorpha. Therefore, these willow patches have the highest understory density in the flooded zone $\left(\mathrm{NRD}_{50}: 0.29-0.25\right)$. Considerable proportions of the willow forests are dense $(45 \%)$ or very dense $(9 \%)$. It can be explained by 
the fact that the less tall and less closed canopy of willows provides better light conditions for the understory, including invasive species. Besides, the shorter life span of willows (usually 40 years, maximum 120 years; [57]) also provides an opportunity for frequent disturbance; thus, invasive species can occupy the empty niches. In addition, riparian willow stands occur at lower elevations in the floodplain, where standing water can appear. During the last couple of dry years, the water disappeared, which can also be favorable for invasives, as they can quickly occupy the empty surfaces. Besides, the willows rapidly mature, i.e., their crown is rapidly exfoliating [57], allowing good light conditions for the emergence of new species. The dense understory of willows and the abundance of bushy invasives (e.g., Amorpha fruticosa, Acer negundo), and climbing aliens (e.g., Vitis riparia, Enchynocystis lobata), significantly impair flood flow conditions in these patches.

Poplar plantations form homogeneous stands of different bred poplar species (Populus sp.). Mature poplar plantations cover $20 \%$ of the study area, while young plantations cover $12 \%$. The height $(17 \mathrm{~m})$ of mature poplar plantations is similar to that of the willows, but their canopy is slender, with a smaller diameter $(3-5 \mathrm{~m})$. Their vegetation density $\left(\mathrm{NRD}_{50}\right.$ : $0.12-0.24$ ) is ideal for flood conveyance, as only $27 \%$ of the mature poplar plantations belong to the dense and $4 \%$ to the very dense vegetation category. The young poplar plantations are short $\left(\mathrm{H}_{\text {mean }}: 9 \mathrm{~m}\right)$, and their canopy is very slim (only $1 \mathrm{~m}$ wide). Their vegetation density $\left(\mathrm{NRD}_{50}: 0.04-0.07\right)$ is the most ideal from the point of view of flood conveyance, as only $7 \%$ of them belong to the dense and $1 \%$ to the very dense vegetation categories. As the poplar forests are artificially planted, their understory is periodically maintained, especially in young plantations. Therefore, the invasive shrubs in young poplar plantations are very sparse compared to other vegetation patches, as foresters can only ensure the sufficiently rapid initial growth of the poplar by clearing other species around them that compete for light and nutrients. Therefore, the young poplar plantations are constantly managed, providing the best conditions for flood conveyance.

The Amorpha thickets form almost homogeneous stands on fallow lands or in forest clearances. Amorpha fruticosa is an invasive plant species of North American origin. It is light-demanding and overgrows rapidly into a spreading shrub under favorable conditions $[57,58]$. From the view of flood conveyance, vegetation density conditions are highly unfavorable in this vegetation type. It usually creates $4-5 \mathrm{~m}$ high, dense stands (NRD mean: $0.051-0.017$ ), and $45 \%$ of the Amorpha stands to belong to the dense and $11 \%$ to the very dense vegetation category.

However, the clearance of Amorpha thickets only is not a solution for the ecological and hydrological problems, as their areal proportion is small, and the invasive Amorpha is common in every riparian forest type. Therefore, the proper management of the riparian vegetation (i.e., clearance of invasive plants) can result in flood level decrease $[2,9,19,40]$, which is a target of lowland flood control but also can support the survival of native species [26,58]. It is also important to note that forests can effectively control the spread of invasive species, as under their closed canopy, the light conditions are not favorable for the growth of heliophylous invasive plants $[57,58]$. Therefore, the attention of landowners should be drawn to the importance of weeding the invasive plant species after any disturbance. In this way, the ecological diversity of the riparian corridor could be preserved, and in the understory canopy layer the flood conveyance could also be supported [23].

\subsection{Spatial Characteristics of the Riparian Vegetation}

The spatial distribution of vegetation density reflects that dense to very dense vegetation patches are characteristic on one-third of the studied floodplain. They are especially abundant along the riverbed and in the southern part of the area, near the highway bridge. Thus, the flood wave entering the floodplain faces a significant roughness increase, resulting in slower flow towards the distal parts of the confined floodplain and accelerated sedimentation in this zone. As in the southern part of the study area, the understory vegetation is also very dense. Combined with the blocking effect of the bridge, substantial impoundment can develop, which can increase flood levels in the impounded section. 
However, to reveal the exact rate of these processes, hydrological modelling is needed in the future.

The vertical changes in vegetation density suggest that in all inundated (1-5 m) zones of the vegetation (up to the level of the artificial levees), the vegetation creates a considerable obstacle in all height zones, as medium and dense vegetation density categories are common in the entire volume. However, there is a slight difference between the vegetation density of the lowermost and uppermost understory zones; thus, the flood conveyance is slightly less blocked by the vegetation in case of high, centurial floods.

\subsection{Methodological Suggestions for Identification and Vegetation Density Measurements}

Light conditions differ substantially between vegetation types and within a patch, as they allow different environments for the growth of shrubs and herbs. Light availability and disturbance regulate the spread of invasive plants, which are usually photophilous [58]. Therefore, the understory density is different even within a seemingly homogenous forest, as various light conditions exist along the edges or a road. Thus, calculating the vegetation density in non-homogeneous vegetation types is very important if someone wants to model any processes influenced by vegetation density (e.g., floods, fires, aeolian process). We suggest that the analyses should be carried out in two steps: first, the vegetation types should be identified, and then the vegetation density within the types needs to be determined.

The applied and presented machine learning classification method is suitable for identifying various vegetation types based on airborne LiDAR imagery even in areas with dense vegetation, where field measurements could hardly be made. The presented method could be used to accurately identify land cover types (e.g., forest, meadow) and their sub-classes (e.g., forest types). In our case, the field validation (at 72 points) reflects $83 \%$ classification accuracy, which is higher than the accuracy of the classification made by Saarinen et al. [54] or Michez et al. [55], and slightly lower than obtained by Madsen et al. [56].

However, some weaknesses in the classification were revealed too. In areas with non-homogeneous vegetation, such as the Tisza floodplain, the main problem is that the canopy of the large trees extends across the boundaries of the vegetation patches and influences the characteristics of the LiDAR point cloud. The more significant the difference in height between the vegetation of adjacent patches, the greater and more frequent this error becomes. Another problem is that vegetation types can be mixed in the $15 \times 15 \mathrm{~m}$ pixels, as the boundaries of vegetation patches do not coincide with the grid boundaries.

Our study proved that the applied NRD vegetation density calculation method [following 27] is suitable even in heavily vegetated areas. In general, the higher the point cloud density, the more accurately the understory vegetation density can be determined. Based on the literature [28,32], a point density of 4 points $/ \mathrm{m}^{2}$ is the lower limit for understory vegetation density analysis in forests. In the study area, the average point cloud density was 9 points $/ \mathrm{m}^{2}$; however, some non-visible patches were still apparent in the understory. Unfortunately, field validation of density measurements was not feasible, as the LiDAR survey was made five years before the analysis. This period was enough to change the understory vegetation (some plots were weeded, cleared, others were abandoned, and invasive plants occupied them).

\section{Conclusions}

In heterogeneous, densely vegetated areas, it is challenging to measure vegetation density by field survey. However, we offer a new combination of methods, which could be applied to large areas, and the vegetation density could be surveyed quickly and repeatedly. The combination of applied machine learning and statistical analysis of a LiDAR point cloud representing the vegetation enables the researchers and managers to determine vegetation density and vegetation conditions of various vegetation types for various reasons. The applied methodology can be extended spatially to large areas; thus, the $3 \mathrm{D}$ vegetation density could be calculated as an input parameter for various models. 
The advantage of the method is that LiDAR images can be rapidly processed using machine learning to obtain up-to-date information on vegetation type and density. The results can be used in a wide range of applications. In water management practice, the use of vegetation density maps allows more accurate modelling of flood events. However, future measurements are needed to transform the understory vegetation density data into vegetation roughness value to fit into Manning's roughness. Only after these precise measurements and their validation, the data could be applied in hydrological models. The results could be directly used in the careful planning of low-density vegetation patches to create flood flow paths, and by the applied method, the vegetation maintenance could be effectively monitored and controlled. The spread of solid pollutants (e.g., micro- and macroplastics) on the floodplains also requires knowledge of understory vegetation density, as macroplastics can be trapped in dense vegetation, whereas the high friction decreases the flow velocity thus, supporting the accumulation of microplastics.

The results can also be applied in forestry, as vegetation type and density maps could help plan forest management. The statistical parameters of forest patches can be quickly and accurately determined, allowing forestry works to be precisely scheduled. Furthermore, the results can provide useful information for disaster management and fire brigades, as the spread of a potential forest fire could be calculated, and the most effective route of intervention could be planned. Determining the density of shrubs and forests can also play an essential role in wildlife management, as different animals prefer different canopies for feeding or hiding places.

The main drawback of the presented methodology is the high financial investment and expertise required for LiDAR-based surveys. However, nowadays, it is becoming increasingly cost-effective and accessible. Based on current trends, LiDAR-based machine learning methods are the most accurate for determining vegetation type and density in large areas, and their role will probably increase in the future in science and management.

Author Contributions: Evaluating floodplain vegetation and density, writing: I.F.; conceptualization, review and editing: T.K. All authors have read and agreed to the published version of the manuscript.

Funding: This research was funded by the Hungarian Research Foundation, grant number OTKA No. 119193 and 134306.

Institutional Review Board Statement: Not applicable.

Informed Consent Statement: Not applicable.

Data Availability Statement: LiDAR data were provided by the Directorate for Environmental Protection and Water Management of Lower Tisza District (ATIVIZIG).

Conflicts of Interest: The authors declare no conflict of interest.

\section{References}

1. EEA. Floodplains: A Natural System to Preserve and Restore; European Environment Agency Report; Publications Office of the European Union: Luxembourg, 2020.

2. Klijn, F.; Asselman, N.; Wagenaar, D. Room for rivers: Risk reduction by enhancing the flood conveyance capacity of the Netherlands' Large Rivers. Geosciences 2018, 8, 224. [CrossRef]

3. Czuba, J.A.; Czuba, C.R.; Magirl, C.S.; Voss, F.D. Channel-Conveyance Capacity, Channel Change, and Sediment Transport in the Lower Puyallup, White, and Carbon Rivers, Western Washington; US Department of the Interior, US Geological Survey: Tacoma, DC, USA, 2010.

4. Chow, V.T. Open Channel Hydraulics; McGraw-Hill: New York, NY, USA, 1959; p. 728.

5. Mikuś, P.; Wyżga, B.; Walusiak, E.; Zawiejska, J. Island development in a mountain river subjected to passive restoration: The Raba River, Polish Carpathians. Sci. Total Environ. 2019, 660, 406-420. [CrossRef]

6. Apollonio, C.; Petroselli, A.; Manzari, V.; Preti, F.; Grimaldi, S. Riparian vegetation as a marker for bankfull and management discharge evaluation. The case study of Rio Torbido river basin (central Italy). J. Agric. Eng. 2021, 52, 2. [CrossRef]

7. Abu-Aly, T.R.; Pasternack, G.B.; Wyrick, J.R.; Barker, R.; Massa, D.; Johnson, T. Effects of LiDAR-derived, spatially distributed vegetation roughness on two-dimensional hydraulics in a gravel-cobble river at flows of 0.2 to 20 times bankfull. Geomorphology 2014, 206, 468-482. [CrossRef]

8. Shan, Y.; Huang, S.; Liu, C.; Guo, Y.; Yang, K. Prediction of the depth-averaged two-dimensional flow direction along a meander in compound channels. J. Hydrol. 2018, 565, 318-330. [CrossRef] 
9. Kiss, T.; Nagy, J.; Fehérváry, I.; Vaszkó, C. (Mis)management of floodplain vegetation: The effect of invasive species on vegetation roughness and flood levels. Sci. Total Environ. 2019, 686, 931-945. [CrossRef]

10. Sándor, A. Floodplain Aggradation along the Middle and Lowland section of the River Tisza. Ph.D. Thesis, Szeged University, Szeged, Hungary, 2011; p. 121. (In Hungarian).

11. Wu, W.; He, Z. Effects of vegetation on flow conveyance and sediment transport capacity. Int. J. Sediment Res. 2009, 24, 247-259. [CrossRef]

12. Järvelä, J. Flow resistance of flexible and stiff vegetation: A flume study with natural plants. J. Hydrol. 2009, 269, 44-54. [CrossRef]

13. Liu, D.; Diplas, P.; Fairbanks, J.D.; Hodges, C.C. An experimental study of flow through rigid vegetation. J. Geophys. Res. 2008, 113, 1-16. [CrossRef]

14. Luhar, M.; Rominger, J.; Nepf, H. Interaction between flow, transport and vegetation spatial structure. Environ. Fluid Mech. 2008, 8, 423. [CrossRef]

15. Larsen, L.G. Multiscale flow-vegetation-sediment feedbacks in low-gradient landscapes. Geomorphology 2019, 334, 165-193. [CrossRef]

16. Jeffries, R.; Darby, S.E.; Sear, D.A. The influence of vegetation and organic debris on flood-plain sediment dynamics: Case study of a low-order stream in the New Forest, England. Geomorphology 2003, 51, 61-80. [CrossRef]

17. Osterkamp, W.R.; Hupp, C.R. Fluvial processes and vegetation-Glimpses of the past, the present, and perhaps the future. Geomorphology 2010, 116, 274-285. [CrossRef]

18. Gurnell, A.M. Plants as river system engineers. Earth Surf. Process. Landf. 2014, 39, 4-25. [CrossRef]

19. Tabacchi, E.; Lambs, L.; Guilloy, H.; Planty-Tabacchi, A.M.; Muller, E.; Décamps, H. Impacts of riparian vegetation on hydrological processes. Hydrol. Process. 2000, 14, 16-17. [CrossRef]

20. Errico, A.; Pasquino, V.; Maxwald, M.; Chirico, G.B.; Solarie, L.; Pretia, F. The effect of flexible vegetation on flow in drainage channels: Estimation of roughness coefficients at the real scale. Ecol. Eng. 2018, 120, 411-420. [CrossRef]

21. Griffin, E.R.; Perignon, M.C.; Friedman, J.M.; Tucker, G.E. Effects of woody vegetation on overbank sand transport during a large flood, Rio Puerco, New Mexico. Geomorphology 2017, 207, 30-50. [CrossRef]

22. Stella, J.C.; Rodríguez-González, P.M.; Dufour, S.; Bendix, J. Riparian vegetation research in Mediterranean-climate regions: Common patterns, ecological processes, and considerations for management. Hydrobiologia 2013, 719, 291-315. [CrossRef]

23. Delai, F.; Kiss, T.; Nagy, J. Field-based estimates of floodplain roughness along the Tisza River (Hungary): The role of invasive Amorpha fruticosa. Appl. Geogr. 2018, 90, 96-105. [CrossRef]

24. Nagy, J.; Kiss, T.; Fehérváry, I.; Vaszkó, C. Changes in floodplain vegetation density and the impact of invasive Amorpha fruticosa on flood conveyance. J. Environ. Geogr. 2018, 11, 3-12. [CrossRef]

25. Boscutti, F.; Pellegrini, E.; Casolo, V.; de Nobili, M.; Buccheri, M.; Alberti, G. Cascading effects from plant to soil elucidate how the invasive Amorpha fruticosa L. impacts dry grasslands. J. Veg. Sci. 2020, 31, 667-677. [CrossRef]

26. Demeter, L.; Molnar, A.P.; Bede-Fazekas, Á.; Ollerer, K.; Varga, A.; Szabados, K.; Tucakov, M.; Kis, A.; Biró, M.; Marinkov, J.; et al. Controlling invasive alien shrub species, enhancing biodiversity and mitigating flood risk: A win-win-win situation in grazed floodplain plantations. J. Environ. Manag. 2021, 295, 113053. [CrossRef]

27. Warmink, J.J. Vegetation Density Measurements Using Parallel Photography and Terrestrial Laser Scanning. Master's Thesis, Utrecht University, Utrecht, The Netherlands, 2007; p. 118.

28. Campbell, M.J.; Dennison, P.E.; Hudak, A.T.; Parham, L.M.; Butler, B.W. Quantifying understory vegetation density using small-footprint airborne LiDAR. Remote Sens. Environ. 2018, 215, 330-342. [CrossRef]

29. Seielstad, C.A.; Queen, L.P. Using Airborne Laser Altimetry to Determine Fuel Models for estimating fire behaviour. J. For. 2003, 101, 10-15.

30. Chasmer, L.; Hopkinson, C.; Treitz, P. Investigating laser pulse penetration through a conifer canopy by integrating airborne and terrestrial LiDAR. Can. J. Remote Sens. 2006, 32, 116-125. [CrossRef]

31. Morsdorf, F.; Marell, A.; Koetz, B.; Cassagne, N.; Pimont, F.; Rigolot, E.; Allgöwer, B. Discrimination of vegetation strata in a multi-layered Mediterranean forest ecosystem using height and intensity information derived from airborne laser scanning. Remote Sens. Environ. 2010, 114, 1403-1415. [CrossRef]

32. Hahmraz, H.; Contreras, M.A.; Zhang, J. Forest understory trees can be segmented accurately within sufficiently dense airborne laser scanning point clouds. Sci. Rep. 2017, 7, 6770. [CrossRef]

33. Campbell, M.J.; Dennison, P.E.; Butler, B.W. A LiDAR-based analysis of the effects of slope, vegetation density, and ground surface roughness on travel rates for wildland firefighter escape route mapping. Int. J. Wildland Fire 2017, 26, 884-895. [CrossRef]

34. Singh, K.K.; Davis, A.J.; Meentemeyer, R.K. Detecting understory plant invasion in urban forests using LiDAR. Int. J. Appl. Earth Obs. Geoinf. 2015, 38, 267-279. [CrossRef]

35. Riaño, D.; Valladares, F.; Condés, S.; Chuvieco, E. Estimation of leaf area index and covered ground from airborne laser scanner (Lidar) in two contrasting forests. Agric. For. Meteorol. 2004, 124, 269-275. [CrossRef]

36. Hudak, A.T.; Crookston, N.L.; Evans, J.S.; Hall, D.E.; Falkowski, M.J. Nearest neighbour imputation of species-level, plot-scale forest structure attributes from LiDAR data. Remote Sens. Environ. 2008, 112, 2232-2245. [CrossRef]

37. Jakubowksi, M.K.; Guo, Q.; Collins, B.; Stephens, S.; Kelly, M. Predicting surface fuel models and fuel metrics using lidar and CIR imagery in a dense mixed conifer forest. Photogramm. Eng. Remote Sens. 2013, 79, 37-49. [CrossRef]

38. Martinuzzi, S.; Vierling, L.A.; Gould, W.A.; Falkowski, M.J.; Evans, J.S.; Hudak, A.T.; Vierling, K.T. Mapping snags and understory shrubs for a LiDAR-based assessment of wildlife habitat suitability. Remote Sens. Environ. 2009, 113, 2533-2546. [CrossRef] 
39. Goodwin, N.R.; Coops, N.C.; Bater, C.; Gergel, S.E. Assessment of sub-canopy structure in a complex coniferous forest. In Proceedings of the ISPR Workshop “Laser Scanning 2007 and SilviLaser 2007”, Espoo, Finland, 12-14 September 2007; pp. 169-172.

40. Kiss, T.; Nagy, J.; Fehérváry, I.; Amissah, J.G.; Fiala, K.; Sipos, G. Increased flood height driven by local factors on a regulated river with a confined floodplain, Lower Tisza, Hungary. Geomorphology 2021, 389, 108858. [CrossRef]

41. Skowronski, N.; Clark, K.; Nelson, R.; Hom, J.; Patterso, M. Remotely sensed measurements of forest structure and fuel loads in the pinelands of New Jersey. Remote Sens. Environ. 2007, 108, 123-129. [CrossRef]

42. USDA Forest Service. First Order LiDAR Metrics: A Supporting Document for Lidar Deliverables. 2014. Available online: https: //www.fs.fed.us/eng/rsac/lidar_training/pdf/LidarMetricsDescriptionOfDeliverables_Generic_12_15_14.pdf (accessed on 7 October 2017).

43. Lászlóffy, W. The Tisza; Akadémiai Kiadó: Budapest, Hungarian, 1982; p. 610. (In Hungarian)

44. Kiss, T. Alterations of Fluvial Processes Due to Anthropogenic Impacts: Study on Equilibrium and Sensitivity in Fluvial Environment. Ph.D. Thesis, University of Szeged, Hungary, 2014; p. 164. (In Hungarian)

45. Kiss, T.; Fiala, K.; Sipos, G.; Szatmári, G. Long-term hydrological changes after various river regulation measures: Are we responsible for flow extremes? Hydrol. Res. 2019, 50, 417-430. [CrossRef]

46. Amissah, G.J.; Kiss, T.; Fiala, K. Morphological Evolution of the Lower Tisza River (Hungary) in the 20th century in response to human interventions. Water 2018, 10, 884. [CrossRef]

47. Laes, D.; Mellin, T.; Wilcox, C.; Anhold, J.; Maus, P.; Falk, D.A.; Koprowski, J.; Drake, S.; Dale, S.; Fisk, H.; et al. Mapping Vegetation Structure in the Pinaleño Mountains Using Lidar; U.S. Department of Agriculture, Forest Service, Remote Sensing Applications Center RSAC-0118-RPT1: Salt Lake City, UT, USA, 2009; 84p.

48. Wilson, D.; Fleig, A.K.; Lawrence, D.; Hisdal, H.; Pettersson, L.; Holmqvist, E. A Review of NVE's Flood Frequency Estimation Procedures; Norwegian Water Resources and Energy Directorate: Oslo, Norway, 2011; Volume 52.

49. McGaughey, R. Users Manual of Fusion/LDV: Software for LIDAR Data Analysis and Visualization; United States Department of Agriculture, Forest Service, Pacific Northwest Research Station: Seattle, WA, USA, 2018; p. 217.

50. Pedregosa, F.; Varoquaux, G.; Gramfor, A.; Michel, V.; Thirion, B.; Grisel, O.; Blondel, M.; Prettenhofer, P.; Weiss, R.; Dubourg, V.; et al. Scikit-learn: Machine Learning in Python. J. Mach. Learn. Res. 2011, 12, 2825-2830.

51. Grabmeier, J.L.; Lambe, L.A. Decision trees for binary classification variables grow equally with the Gini impurity measure and Pearson's chi-square test. Int. J. Bus. Intell. Data Min. 2007, 2, 213. [CrossRef]

52. Bengio, Y.; Grandvalet, Y. No unbiased estimator of the variance of K-Fold cross-validation. J. Mach. Learn. Res. 2004, 5, 1089-1105.

53. Schaffer, C. Overfitting Avoidance as Bias. Mach. Learn 1993, 10, 153-178. [CrossRef]

54. Saarinen, N.; Vastaranta, M.; Vaaja, M.; Lotsari, E.; Jaakkola, A.; Kukko, A.; Kaartinen, H.; Holopainen, M.; Hyyppä, H.; Alho, P. Area-based approach for mapping and monitoring riverine vegetation using mobile laser scanning. Remote Sens. 2013, 5, 5285-5303. [CrossRef]

55. Michez, A.; Piégay, H.; Jonathan, L.; Claessens, H.; Lejeune, P. Mapping of riparian invasive species with supervised classification of Unmanned Aerial System (UAS) imagery. Int. J. Appl. Earth Obs. Geoinf. 2016, 44, 88-94. [CrossRef]

56. Madsen, B.; Treier, U.A.; Zlinszky, A.; Lucieer, A.; Normand, S. Detecting scrub encroachment in seminatural grasslands using UAS LiDAR. Ecol. Evol. 2020, 10, 4876-4902. [CrossRef]

57. Gencsi, L.; Vancsura, R. Dendrology; Mezőgazda Kiadó: Budapest, Hungarian, 1997; p. 730. (In Hungarian)

58. Mihály, B.; Botta-Dukát, Z. Invasive Plants; Természet BÚVÁR Alapítvány Kiadó: Budapest, Hungarian, 2004; p. 366. (In Hungarian) 